\title{
A SOCIEDADE DA INFORMAÇÃO A FAVOR DA DEMOCRACIA: O DIREITO DA INFORMAÇÃO E LIVRE ESCOLHA NO CONSUMO DE ALIMENTOS TRANSGÊNICOS ${ }^{1}$
}

\section{THE INFORMATION SOCIETY IN FAVOR OF DEMOCRACY: THE RIGHT TO INFORMATION AND FREEDOM OF CHOICE IN CONSUMPTION OF TRANSGENIC FOOD}

\author{
Brisa Arnoud da Silva
}

\begin{abstract}
RESUMO
O presente estudo tem como objetivo enfatizar a importância da informação frente as transformações sociais e científicas que ocorrem na pós-modernidade. A pesquisa justifica-se diante da percepção de diferentes obstáculos que se colocam frente ao acesso à informação idônea, não obstante o auge da Sociedade da Informação. Interesses políticos e econômicos afirmam-sedominantes com estratégias de manipulação da informação, com aprogressiva massificação de informação ao consumo imediatista; com o artifício do marketing empresarial da maquiagem verde de produtos e serviços (greenwashing); com a omissão de rotulagem e informação em produtos e alimentos transgênicos e banalização dos riscos socioambientais. Desse modo, é oferecida uma descrição dos direitos e deveres à informação, à informação ambiental e informação do consumidor do Estado Socioambiental de Direito visando conscientizar o sujeito-consumidor sobre sua atuação positiva na sociedade, e instrumentalizar a participação e controle social. $\mathrm{O}$ artigo foi desenvolvido pelo método ${ }^{2}$ indutivo $^{3}$, por pesquisa bibliográfica ${ }^{4}$ e demais técnicas do referente ${ }^{5}$ e categoria ${ }^{6}$.
\end{abstract}

Palavras-chaves: Sociedade da Informação. Consumo. Estado Socioambiental de Direito. Direito à informação. Rotulagem de transgênicos.

\begin{abstract}
This study aims to emphasize the importance of information across the social and scientific changes that occur in post-modernity. The research is justified on the perception of different obstacles concerning the access to reputable information,
\end{abstract}

\footnotetext{
* Mestranda no Programa de Pós-graduação stricto sensu em Ciência Jurídica da Universidade do Vale do Itajaí - Univali/SC). Advogada, especializada em Direito do Estado pela Universidade Anhanguera-Uniderp. Extensão em Instrumentos de Gestão Ambiental Empresarial pela Fundação Getúlio Vargas-FGV. Graduada em Direito pela Universidade do Sul de Santa Catarina - Unisul/SC.

${ }^{1}$ Artigo elaborado para a disciplina Estado Contemporáneo y Derecho Ambiental, ministrada pelo Prof. Dr. Gabriel Real Ferrer, no Programa de Pós-graduação stricto sensu em Ciência Jurídica da Universidade do Vale do Itajaí-Univali.

2 "Método é forma lógico-comportamental na qual se baseia o Pesquisador para investigar, tratar os dados colhidos e relatar os resultados". PASOLD, Cesar Luiz. Metodologia da Pesquisa Jurídica: Teoria e Prática. 11. ed. Florianópolis: Conceito Editorial/Millenium, 2008. p. 85.

3 "Base lógica da dinâmica da Pesquisa Científica que consiste em pesquisar e identificar as partes de um fenômeno e coleciona-las de modo a ter uma percepção ou conclusão geral. PASOLD, Cesar Luiz. Metodologia da Pesquisa Jurídica: Teoria e Prática. 11. ed. Florianópolis: Conceito Editorial/Millenium, 2011 . p. 205.

4 “Técnica de investigação em livros, repertórios jurisprudenciais e coletâneas legais". PASOLD, Cesar Luiz. Metodologia da Pesquisa Jurídica: Teoria e Prática. 11. ed. Florianópolis: Conceito Editorial/Millenium, 2008. p. 103.

5 "Explicação prévia do motivo, objetivo e produto desejado, delimitado o alcance temático e de abordagem para uma atividade intelectual, especialmente para uma pesquisa”. PASOLD, Cesar Luiz. Metodologia da Pesquisa Jurídica: Teoria e Prática. 11. ed. Florianópolis: Conceito Editorial/Millenium, 2008. p. 54.

6 "Palavra ou expressão estratégica à elaboração e/ou expressão de uma ideia". PASOLD, Cesar Luiz. Metodologia da Pesquisa Jurídica: Teoria e Prática. 11. ed. Florianópolis: Conceito Editorial/Millenium, 2008. p. 25.
} 


\begin{abstract}
regardless of the importance of the Information Society. Political and economic interests are dominant with strategies of manipulation of information, with the progressive massification of information consumption; with the artifice of corporate marketing for the green make up of products and services (greenwashing); with the omission of labeling and information on products and transgenic food and trivialization of social and environmental risks. Thus, this study describes the rights and duties of information, environmental information and consumer information in the State of Social and Environmental Law aim ing to promote awareness in the subject-consumer on their positive action in society, and instrumentalize the participation and social control. The article was developed according to the inductive method, bibliography icresearch and other referent and category techniques.
\end{abstract}

Keywords: Information Society. Consumption. State of Social and Environmental Law. Right to information. Genetically modified foods. Labeling of GMOs.

"Você é livre para fazer suas escolhas, mas prisioneiro das consequências".

(Pablo Neruda, poeta chileno, 1904-1973)

\section{Introdução}

Nesse estágio da modernidade em que constatamos os resultados do modelo desenvolvimentista de crescimento a todo custo da Sociedade de Risco ${ }^{7}$, a informação revela-se como instrumento essencial para a participação democrática nas escolhas e decisões que afetam toda a sociedade.

Os interesses econômicos que permeiam toda a Sociedade da Informação refletem na multidão de consumidores e como sabemos, o nosso comportamento social propaga efeitos sob todo o ambiente, que repercutem diretamente na qualidade de vida, bem-estar e dignidade humana. Desse modo, o diálogo didático do Direito à informação deflagra expoente papel-instrumento à conscientização do sujeito-consumidor sobre as ameaças à saúde e a vida e para sua atuação positiva na comunidade.

A convergência dos direitos à informação, informação ambiental e informação do consumidorbusca articular o enfrentamento da manipulação da

\footnotetext{
${ }^{7}$ FREITAS, Juarez. Sustentabilidade: direito ao futuro. p. 27: "A 'sociedade de risco' constata os resultados do modelo de desenvolvimento industrial de crescimento a todo custo. A expressão traduz o estado de insegurança, de iminente desgraça e riscos pluridimensionais desencadeados pelos efeitos imprevisíveis da ação predatória, cumulada e inconsequente do modelo de produção e consumo da sociedade industrial, capaz de pôr em xeque o futuro da humanidade e a vida na Terra". (Grifo do autor).
}

informação, que afetam o mundo, modifica pensamentos e vontades e provoca riscos socioambientais, para intensifica a luta pelo controle social, intrinsecamente relacionada a defesa da dignidade humana, no contexto complexo da Sociedade de Risco, da Informação, de consumo, a exemplo da reivindicação da rotulagem de alimentos transgênicos para o exercício da livre escolha e consumo consciente.

A pesquisa foi elaborada pelo método ${ }^{8}$ induti$\mathrm{vo}^{9}$, por pesquisa bibliográfica ${ }^{10}$ e técnicas do Referente $^{11}$ e Categoria ${ }^{12}$.

\footnotetext{
8 "Método é forma lógico-comportamental na qual se baseia o Pesquisador para investigar, tratar os dados colhidos e relatar os resultados". PASOLD, Cesar Luiz. Metodologia da Pesquisa Jurídica: Teoria e Prática. 11. ed. Florianópolis: Conceito Editorial/Millenium, 2008. p. 85.

9 "Base lógica da dinâmica da Pesquisa Científica que consiste em pesquisar e identificar as partes de um fenômeno e coleciona-las de modo a ter uma percepção ou conclusão geral. PASOLD, Cesar Luiz. Metodologia da Pesquisa Jurídica: Teoria e Prática. 11. ed. Florianópolis: Conceito Editorial/ Millenium, 2011. p. 205.

10 "Técnica de investigação em livros, repertórios jurisprudenciais e coletâneas legais". PASOLD, Cesar Luiz. Metodologia da Pesquisa Jurídica: Teoria e Prática. 11. ed. Florianópolis: Conceito Editorial/Millenium, 2008. p. 103.

11 "Explicação prévia do motivo, objetivo e produto desejado, delimitado o alcance temático e de abordagem para uma atividade intelectual, especialmente para uma pesquisa”. PASOLD, Cesar Luiz. Metodologia da Pesquisa Jurídica: Teoria e Prática. 11. ed. Florianópolis: Conceito Editorial/ Millenium, 2008. p. 54.

12 "Palavra ou expressão estratégica à elaboração e/ou expressão de uma ideia”. PASOLD, Cesar Luiz. Metodologia da Pesquisa Jurídica: Teoria Prática. 11. ed. Florianópolis: Conceito Editorial/Millenium, 2008. p. 25.
} 


\section{0 progresso da Sociedade da Informação}

A evolução da Sociedade da Informação ocorreu paulatinamente, com importantes episódios na história da civilização, como a transformação da linguagem simbólica à comunicação humana, marcada na pré-história por gestos, sons e pinturas rupestres. A escrita foi o primeiro grande invento das antigas culturas, no Egito com a escrita hierática e por hieróglifos, e na Mesopotâmia com a escrita cuneiforme, desenvolvidas pela necessidade de controle das informações agrícolas e comerciais, o que estimulou o despontar de vários outros conhecimentos, como Astronomia, Direito (com o precursor Código de Hammurabi), Literatura, Contabilidade, Administração, mas também ligada a registros de rituais sagrados, colheitas, estações ${ }^{13}$.

A origem do papel é atribuída aos chineses em 105 d.C., substituindo peles, pergaminhos, placas de cera e argila, madeira e metal. A fabricação de papel chegou na Europa no século XII, e em 1455 foi gerada a prensa pelo alemão Johannes Gutemberg, possibilitando a impressão rápida e a redução de custos, transformando e facilitando a disseminação de informação e conhecimento, porque antes os pergaminhos eram manuscritos, num dispendioso processo artesanal. Em 1837 o inglês Charles Babbage, intitulado "pai do computador", projetou a máquina analítica, considerada o primeiro computador de uso geral, ainda movida a vapor. Em 1877 a criação do telefone pelo americano Graham Bell permitiu a comunicação e transmissão de informação à longa distância. No final da década de 1960 desenvolveram os primeiros microcomputadores, e com o computador aliado à telefonia, se viabilizou a internet. A inovação dos microchips manifesta, enfim, a evidente marcha revolucionária da Sociedade da Informação ${ }^{14}$.

Na pré-história, o homem vivia da caça e da coleta de plantas e frutas. Na revolução agrícola, com a domesticação dos animais. Na revolução industrial o homem passou a dominar as máquinas, e o desenvolvimento das máquinas a vapor e a eletricidade também promoveu a eclosão de automóveis, telefones e computadores, que consequentemente

\footnotetext{
${ }^{13}$ GOMES, Eduardo de Castro. A escrita na história da humanidade. Disponível em: http://dialogica.ufam.edu.br/PDF/no3/Eduardo_Aspectos_da escrita_na_Historia_da_humanidade.pdf. Acesso em: 24 set. 2014 .

${ }^{14}$ LISBOA, Roberto Senise. Direito na sociedade da informação. Revista dos Tribunais. Ano. 95, vol. 847, mai.-2006, p. 78-95, p. 79-84.
}

impulsionou a comunicação, o conhecimento e sua propagação. Na Sociedade da Informação, a fonte de valor e poder é a informação, que desdobrada pelo Neoliberalismo e o fenômeno da globalização, progrediu com expressão desde o fim do século XX, com investimentos em infraestrutura e tecnologia na transmissão de informação ${ }^{15}$.

A Sociedade da Informação, também chamada de revolução da informação, era da informação, infoera, sociedade em rede, revolução digital, cibersociedade, é termo atribuído a esse cenário que canaliza e aprimora os meios de comunicação e possibilita a interação coletivizada da informação ${ }^{16}$.

A informação é entendida de múltiplas maneiras, por uns como mensagem, por outros como conteúdo ${ }^{17}$, assim, num significado enviado por meio de um anúncio ${ }^{18}$, que pressupõe o esforço inerente de passar a informação e, ao mesmo tempo, provocar sua recolha, percepção, adoção ${ }^{19}$.

Segundo Paulo Affonso Leme Machado a informação é um registro do que existe ou do que está em processo de existir. Informar é transmitir conhecimento, e no que dissemina, soma. A informação traduz-se como instrumento para educação e ferramenta de participação dos indivíduos na sociedade ${ }^{20}$.

Leonardo Boff pondera que a recolha e assimilação, em cada pessoa, é diferente, porque o entendimento depende de uma interpretação, e "Para compreender, é essencial conhecer o lugar social de quem olha"21.

Para Edgar Morin, "Significa dizer que a informação não é um conceito de chegada, é um conceito ponto de partida" 22 .

\footnotetext{
${ }^{15}$ SIQUEIRA JR., Paulo Hamilton. Direito informacional: direito da sociedade da informação. Revista dos Tribunais, ano 96, vol. 859, mai. 2007, p. 743- 759, p. 744-748.

${ }^{16}$ LISBOA, Roberto Senise. Direito na sociedade da informação. Revista dos Tribunais. Ano. 95, vol. 847, mai.-2006, p. 78-95, p. 85.

${ }^{17}$ SIQUEIRA JR., Paulo Hamilton. Direito informacional: direito da sociedade da informação. Revista dos Tribunais, ano 96, vol. 859, mai. 2007, p. 743- 759, p. 749

${ }^{18}$ BARROS, Lucivaldo Vasconcelos. Direito à informação socioambiental e desenvolvimento sustentável. Revista de Direito Ambiental. Ano 12, n. 45, jan.-mar.2007, p. 167-183, p. 170.

${ }^{19}$ SIQUEIRA JR., Paulo Hamilton. Direito informacional: direito da sociedade da informação. Revista dos Tribunais, ano 96, vol. 859, mai. 2007, p. 743- 759, p. 750

${ }^{20}$ MACHADO, Paulo Affonso Leme. Direito ambiental brasileiro. 12. ed. p.78. São Paulo: Malheiros, 2004, p. 263, p. 26.

${ }^{21}$ BOFF, Leonardo. A águia e a galinha: uma metáfora da condição humana. 32 ed. Petrópolis, RJ: Editora Vozes, 1999, p. 9.

${ }^{22}$ MORIN, EDGAR. Introdução ao pensamento complexo. Tradução de
} 
A categoria Sociedade da Informação abrange toda a dinâmica de acessar-reunir-organizar-distribuir, para facilitar o acesso à informação, e o avanço e agilidade dos meios de telecomunicação e microeletrônica, como a internet, o satélite, a telefonia celular e a rede de fibra óptica, modificam as relações sociais, culturais, políticas, econômicas, jurídicas, no mundo. Essas tecnologias, por si só, não transformam a sociedade, mas a maneira como são utilizadas pelas pessoas repercutem as mudanças da Sociedade da Informação ${ }^{23}$.

Os críticos à "Sociedade da Informação" contestam a existência de uma revolução em face da desigualdade do acesso às políticas de inclusão digi$\mathrm{tal}^{24}$. Mas o fato dessas tecnologias ainda não serem acessíveis à milhões de pessoas não nega sua existência, assim como o fato de milhões de pessoas ainda não terem acesso à energia elétrica ${ }^{25}$ não expressa que a revolução industrial não foi uma revolução ${ }^{26}$ :

La tecnología no es, por si mesma, nibuenani mala. Es lautilización que de lamisma se hagala que determinará lanaturaleza y extensión de sus beneficios. Ademásconviene considerar como dichosbeneficios no serán simétricos para todos losciudadanos, ya que losbeneficios y loscostesserán desigualmente repartidos. Mientras que determinados ciudadanos y/o grupos

\footnotetext{
Eliane Lisboa. 3 ed. Porto Alegre: Sulina, 2007, p. 27.

${ }^{23}$ FIORILLO, Celso Antonio Pacheco. Fundamentos constitucionais do meio@mbientedigit@1 na sociedade da informação. In: Paesani, Liliana. O direito na sociedade da informação III: A evolução do direito digital, v.3, Atlas, 2013. VitalBook file. Minha Biblioteca. Disponível em: < http://online. minhabiblioteca.com.br/books/9788522482139>. Acesso em 9 set. 2014. p. 13.

${ }^{24}$ FIORILLO, Celso Antonio Pacheco. Fundamentos constitucionais do meio @mbientedigit@l na sociedade da informação. In:Paesani, Liliana. O direito na sociedade da informação III: A evolução do direito digital, v.3, Atlas, 2013, p. 22: "Segundo os dados da Pesquisa Nacional por Amostra de Domicílios 2008 (PNAD), do IBGE, 65\% dos brasileiros não têm acesso à Internet. São 104,7 milhões de pessoas acima de dez anos de idade, que em sua maioria estão nas regiões Norte e Nordeste, são analfabetas ou estudaram apenas o ensino fundamental, têm acima de 35 anos e pertencem a famílias com renda mensal de até três salários-mínimos. O apagão digital brasileiro reflete o quadro de exclusão social. Vide enciclopédia do estudante, p. 16"; AUGUSTINI, Camila; VARON, Joana; CARIBÉ, Pedro. Wi-fi? Projeto Freenet? Disponível em:<http://www.diplomatique.org.br/ multimidia.php?id=38>. Também em: $<$ http://freenetfilm.org $/>$. Acesso em 27 set. 2014

${ }^{25}$ VITAL Nicholas. Luz para poucos: Apesar de toda a propaganda em torno do programa Luz para Todos, há ainda 2,5 milhões de residências no país sem acesso à energia elétrica. Revista Exame. 29 dez. 2010. Disponível em: $<$ http://planetasustentavel.abril.com.br/noticia/energia/muitas-casas-falta-eletricidade-programa-luz-todos-exame-615327.shtml?func=1\&pag=0\&$\mathrm{fnt}=14 \mathrm{px}>$. Acesso em: 29 set. 2014.

${ }^{26}$ LISBOA, Roberto Senise. Direito na sociedade da informação. Revista dos Tribunais. Ano. 95, vol. 847, mai.-2006, p. 78-95, p. 89.
}

puedenpercibir grandes beneficios, otrospueden ser seriamente perjudicados ${ }^{27}$.

O panorama que se tem quando uma porção da população possui computador, serviço de conexão à internet e acesso à tantas informações, e outra não, espelha um "abismo digital", que repercute nos hábitos e na conduta social, na educação, cultura e integração na sociedade, cada vez mais envolvida nas novas tecnologias. $\mathrm{O}$ abismo digital não diz respeito apenas a ter ou não computador, mas sobretudo na dificuldade de peneirar as inúmeras informações à disposição na rede ${ }^{28}$.

\section{A manipulação da informação na modernidade}

$\mathrm{Na}$ sociedade guiada pelo Neoliberalismo, cada dia o homem precisa de mais informações ${ }^{29} \mathrm{e}$ essa demanda tem se imposto como mecanismo de publicidade, que coloca em circulação notícias, textos, propagandas e embalagens direcionadas à expansão do mercado e indústria ${ }^{30}$.

A tendência da mercantilização progressiva não é claramente percebida pela névoa do excesso de informação ${ }^{31}$. A massificação de informação se coloca como artifício da economia pelo indigesto volume de informações, disseminadas por todos os meios disponíveis, e consequentemente provoca mudanças comportamentais na sociedade, no

\footnotetext{
${ }^{27}$ BRAVO, Álvaro A. Sánchez.Internetylasociedadeuropeadelainformación implicaciones para losciudadanos. Fragmento disponível para visualização em: <http://books.google.com.br/books?id=vgu7ggfCYN4C\&pg=PA12\&l$\mathrm{pg}=\mathrm{PA} 12 \& \mathrm{dq}=$ alvaro $+\mathrm{a}+\mathrm{s} \% \mathrm{C} 3 \% \mathrm{~A} 1 \mathrm{nchez}+\mathrm{bravo}+$ sociedad $+\mathrm{de}+\mathrm{la}+\mathrm{infor}-$ maci\%C3\%B3n\&source $=$ bl\&ots $=$ KQ0 - r7vzSf\&sig $=$ QWT7pTURafDf7X $38 \mathrm{KOc}=-\mathrm{IiFLi0C} \& \mathrm{hl}=$ pt-BR\&sa $=X \&$ ei $=$ aJtLVJ0KLIrxgwSO4zDQCg\&ved -

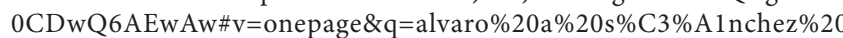
bravo $\% 20$ sociedad $\% 20 \mathrm{de} \% 20 \mathrm{la} \% 20$ informaci $\% \mathrm{C} 3 \% \mathrm{~B} 3 \mathrm{n} \& \mathrm{f}=$ false $>$. Acesso em 25 out. 2014

${ }^{28}$ FIORILLO, Celso Antonio Pacheco. Fundamentos constitucionais do meio@mbientedigit@l na sociedade da informação. In:Paesani, Liliana. O direito na sociedade da informação III: A evolução do direito digital, v.3, Atlas, 2013, p. 22.

${ }^{29}$ BARROS, Lucivaldo Vasconcelos. Direito à informação socioambiental e desenvolvimento sustentável. Revista de Direito Ambiental. Ano 12, n. 45 , jan.-mar.2007, p. 167-183, p. 170.

${ }^{30}$ SILVA, Telma Domingues da. Educação ambiental: a educação para o consumo na sociedade da informação. Linguagem em (Dis)curso [online], Tubarão, SC, v. 11, n. 3, p. 563-584, set./dez. 2011, p. 570. Disponível em: < http://www.scielo.br/scielo.php?script=sci_arttext\&pi$\mathrm{d}=$ S1518-76322011000300006\&lng=en\&nrm=iso $>$. Acesso em: 11 set. 2014 . ${ }^{31}$ BAUMAN, Zygmunt. Vida para consumo: a transformação das pessoas em mercadoria. Tradução Carlos Alberto Medeiros. Rio de Janeiro: Zahar, 2008 , p. 54
} 
entanto, não aquelas almejada para a compreensão da importância das concepções ambientais para a qualidade de vida ${ }^{32}$. Tanta informação dirigida apenas ao consumo provoca a dispersão do pensamento humano como numa hipnose, relegando questões como preservação ambiental, qualidade de vida, saúde, bem-estar geral ${ }^{33}$.

Zygmunt Bauman em "Vida para consumo: a transformação das pessoas em mercadoria", aborda a transformação comportamental dos indivíduos no período industrial e pós-industrial na distinção da sociedade sólida (anterior) e líquida (atual), em que os integrantes da sociedade sólida moderna almejavam a estabilidade pelo planejamento e construção da segurança futura, e agora na sociedade líquida moderna buscam a satisfação pela satisfação, no desfrute imediato do prazer sempre insaciável, em que tudo o que é durável e estável torna-se um fardo a ser descartado pela busca de um novo querer. Os fornecedores dos bens de consumo usufruem e estimulam essa influência globalizada e jorram um crescente volume de informação estratégica aos consumidores, à pressionar e impressioná-los o suficiente para adotá-las no curso de suas buscas por um fugaz desejo, e cita como exemplo o progressivo fluxo de informação da indústria da música, que reflete no círculo da moda, do automobilismo..., como uma enxurrada de "novos" lançamentos que contam com a curta memória do público e a fantasia do ideal para cativar o consumidor e movimentar a economia, a exemplo da roupa, do carro dos "grandes pensadores da música popular brasileira", e assim em todas as atividades econômicas, a acarretar, no fim - cada vez mais breve -, em mais lixo ${ }^{34}$.

Como Bauman, Telma Domingues da Silva complementa que após a revolução industrial o cidadão de direitos se transforma no papel do sujeito consumidor. E os sistemas especialistas, nesse momento histórico de críticas aos efeitos e consequências da Sociedade de Risco, que precisam se reafirmar como parte integrante do mercado,

\footnotetext{
${ }^{32}$ LISBOA, Roberto Senise. Direito na sociedade da informação. Revista dos Tribunais. Ano. 95, vol. 847, mai.-2006, p. 78-95, p. 87.

${ }^{33}$ BARROS, Lucivaldo Vasconcelos. Direito à informação socioambiental e desenvolvimento sustentável. Revista de Direito Ambiental. Ano 12, n. 45, jan.-mar.2007, p. 167-183, p. 168-171.

${ }^{34}$ BAUMAN, Zygmunt. Vida para consumo: a transformação das pessoas em mercadoria. Tradução Carlos Alberto Medeiros. Rio de Janeiro: Zahar, 2008, p. 55-57.
}

investem no processo discursivo de qualificação do produto, numa proposta associada a um nicho mercadológico especializado, que mais recentemente se coloca na sociedade vinculada à ideia do desenvolvimento sustentável, sustentabilidade e consumo consciente ${ }^{35}$. O que assinala, porém, é que em virtude da relevância ambiental politizada, a responsabilidade social e ambiental que é da empresa passa a ser transferida ao cidadão-consumidor, vendida como mercadoria requalificada.

Esse nicho de mercado manifesta que o número de produtos que se dizem ecológicos ou sustentáveis tem aumentado no comércio do Brasil e confere ao consumidor, que acredita que a informação contida na embalagem é verídica, uma arma de controle social pelo mercado ${ }^{36}$, que pelo exercício da escolha orienta a demanda de bens e serviços com maior adequação a critérios ambientais, em detrimento de outros, e assim é de se esperar que isso influencie positivamente atitudes e comportamentos empresariais e produza uma reorientação ao setor produtivo para um comportamento ambientalmente mais respeitoso, para aderir à responsabilidade socioambiental ${ }^{37}$.

O mercado de consumo verde consciente considera os reflexos das ações dos consumidores sobre a sociedade, a economia e o ambiente, além da satisfação do consumidor individual ${ }^{38}$.

Mas também demonstra em grande proporção o sintoma da maquiagem verde, em que muitas empresas denominam produtos ecológicos, sem explicar e comprovar o que realmente fazem em favor do ambiente. O termo em inglês greenwashing delata a estratégia de marketing que confunde o consumidor sobre as ações práticas empresariais socioambientais ou os benefícios ambientais de um produto ou serviço. Essas informações débeis e evasivas provocam o constrangimento em si por não fornecerem provas

\footnotetext{
${ }^{35}$ SILVA, Telma Domingues da. Educação ambiental: a educação para o consumo na sociedade da informação. Linguagem em (Dis)curso [online], Tubarão, SC, v. 11, n. 3, p. 563-584, set./dez. 2011, p. 568-570. Disponível em: < http://www.scielo.br/scielo.php?script=sci_arttext\&pi$\mathrm{d}=\mathrm{S} 1518-76322011000300006 \& \operatorname{lng}=$ en\&nrm=iso $>$. Acesso em: 11 set. 2014. ${ }^{36}$ SILVA, Brisa Arnoud da. Do Estado Liberal para Socioambiental de Direito: o caminho para o desenvolvimento sustentável. In: SOUZA, Maria Claudia da Silva Antunes de; ARMADA, Charles Alexandre Souza (Org.). Teoria jurídica e Transnacionalidade. vol. II, 2014, p. 130-152, p. 147. Disponível em: <http://www.univali.br/ppcj/ebook $>$. Acesso em: 21 jul.2014.

37 FERRER, Gabriel Real. La construccióndelderecho ambiental. Revista Aranzadi de Derecho Ambiental. (Pamplona, Espanha), n.1, 2002, p. 73-93. ${ }^{38}$ ALBUQUERQUE, José Lima (Org.). Gestão ambiental e responsabilidade social: conceitos, ferramentas e aplicações. São Paulo: Atlas, 2009, p. 57.
} 
de suas alegações ecologicamente corretas; pela incerteza das declarações vagas e ambíguas que não permitem compreensão clara de qual é a medida que relaciona o valor ambiental; por fazer apelo pontual a uma característica ambiental sem relevar outros critérios de alto impacto na cadeia de produção; por apresentar símbolos que transmite a ideia de certificações que, na prática, não existem; por destacar características que na verdade são obrigações legais; por salientar a característica ecológica de produto ou serviço que por si só provoca prejuízo ao indivíduo e ambiente ${ }^{39}$.

De modo que a condição de transparência e visibilidade das ações e consequências das atividades perpassa a seara pública e a iniciativa privada ao direito à informação.Todos têm direito de acesso à informação e essa garantia é convencionada em diversos diplomas legais.

\section{O direito à informação no Estado Socioambiental de Direito}

A Constituição da República Federativa do Brasil de 1988 - CRFB/88 ao consagrar o regime democrático reconheceu aos cidadãos o direito à informação e consignou o princípio da publicidade ${ }^{40}$ comprometendo-se com a transparência e compartilhamento de informações com os cidadãos, num direito de "receber dos órgãos públicos informações adequadas, claras, precisas, completas e verdadeiras, proibindo qualquer tipo de opacidade nos conteúdos informativos sobre todas as matérias ${ }^{41}$ ".

É possível distinguir duas perspectivas do direito à informação: a subjetiva, em que o acesso a informação e às suas fontes são fundamentais para que os cidadãos entendam a essência e o limite dos seus direitos em face dos poderes públicos; e a objetiva, porque a transparência no processo de tomada de decisão administrativa permite a fiscalização e exige

\footnotetext{
${ }^{39}$ GOERG, Paula. Greenwashing no Brasil: um estudo sobre os apelos ambientais nos rótulos. Disponível em: <http://marketanalysis.com.br/wp-content/uploads/2014/09/Greenwashing_2014_MarketAnalysis.pdf $>$. Acesso em: 6 out. 2014 .

${ }^{40} \mathrm{CRFB} / 88$, art. 37- A administração pública direta e indireta de qualquer dos Poderes da União, dos Estados, do Distrito Federal e dos Municípios obedecerá aos princípios de legalidade, impessoalidade, moralidade, publicidade e eficiência (...).

${ }^{41}$ BARROS, Lucivaldo Vasconcelos. Direito à informação socioambiental edesenvolvimento sustentável. Revista de Direito Ambiental. Ano 12, n. 45, jan.-mar.2007, p. 167-183, p. 168-169.
}

cidadãos informados para tanto - condição de se informarem e serem informados ${ }^{42}$.

A CRFB/88 ao estabelecer o direito de todos ao ambiente ecologicamente equilibrado reconheceu no seu parágrafo $1^{\circ}$, inciso $\mathrm{IV}^{43}$, a publicidade da informação ambiental como instrumento de efetivação desse direito. Isso complementa e especifica em matéria ambiental os direitos enunciados no art. $5^{\circ}$, inc. XIV de acesso à informação ${ }^{44}$, e inc. XXXIII de receber dos órgãos públicos informações de interesse particular, coletivo ou gera ${ }^{45}$, na norma constitucional. Dessa forma, a conjugação dos enunciados nos arts. 225 , caput e $\S 1^{\circ}$, inc. IV, e $5^{\circ}$, incs. XIV e XXXIII, da CRFB/88 estabelece o direito fundamental à informação ambiental.

No ordenamento jurídico pátrio, o art. 14, inc. I, do Decreto n. 99.274, de 6.6.1990 ${ }^{46}$ e art. $8^{\circ}$, da Lei n. 7.347, de $24.7 .1985^{47}$ consolidam o dever do Poder Público de fornecer informações regularmente à população sobre o estado do ambiente e fatos importantes (art. $4^{\text {o }}$, inc. $\mathrm{V}^{48}$ e art. $9^{\circ}$, incs. $\mathrm{X}$ e $\mathrm{XI}^{49}$, da Lei

\footnotetext{
${ }^{42}$ GOMES, Carla Amado. A caminho de uma ecocidadania: notas sobre o direito à informação ambiental. Revista de Direito Ambiental. Ano 12, n. 45, jan.-mar.2007, p. 259-272, p. 261-262.

${ }^{43}$ CRFB/88, art. 225- Todos têm direito ao meio ambiente ecologicamente equilibrado, bem de uso comum do povo e essencial à sadia qualidade de vida, impondo-se ao Poder Público e à coletividade o dever de defendê-lo e preservá-lo para as presentes e futuras gerações. $\$ 1^{\circ}$ - Para assegurar a efetividade desse direito, incumbe ao Poder Público: IV - exigir, na forma da lei, para instalação de obra ou atividade potencialmente causadora de significativa degradação do meio ambiente, estudo prévio de impacto ambiental, a que se dará publicidade;

${ }^{44} \mathrm{CRFB} / 88$, art. $5^{\circ}, \mathrm{XIV}$ - é assegurado a todos o acesso à informação e resguardado o sigilo da fonte, quando necessário ao exercício profissional;

${ }^{45} \mathrm{CRFB} / 88$, art. $5^{\circ}$, XXXIII- todos têm direito a receber dos órgãos públicos informações de seu interesse particular, ou de interesse coletivo ou geral, que serão prestadas no prazo da lei, sob pena de responsabilidade, ressalvadas aquelas cujo sigilo seja imprescindível à segurança da sociedade e do Estado; ${ }^{46}$ Dec.n. 99.274/90 - art. 14- A atuação do Sisnama efetivar-se-á mediante articulação coordenada dos órgãos e entidades que o constituem, observado o seguinte: I - o acesso da opinião pública às informações relativas às agressões ao meio ambiente e às ações de proteção ambiental, na forma estabelecida pelo Conama;

${ }^{47}$ Lei n. 7.347/85- art. $8^{\circ}$ Para instruir a inicial, o interessado poderá requerer às autoridades competentes as certidões e informações que julgar necessárias, a serem fornecidas no prazo de 15 (quinze) dias.

${ }^{48}$ Lei $6.938 / 81$, art. 4ํㅡ V- A Política Nacional do Meio Ambiente visará: V - à difusão de tecnologias de manejo do meio ambiente, à divulgação de dados e informações ambientais e à formação de uma consciência pública sobre a necessidade de preservação da qualidade ambiental e do equilíbrio ecológico;

${ }^{49}$ Lei n. 6.938/81, art. 9º- São instrumentos da Política Nacional do Meio Ambiente: X - a instituição do Relatório de Qualidade do Meio Ambiente, a ser divulgado anualmente pelo Instituto Brasileiro do Meio Ambiente e Recursos Naturais Renováveis - IBAMA; XI - a garantia da prestação de informações relativas ao Meio Ambiente, obrigando-se o Poder Público a produzi-las, quando inexistentes;
} 
n. 6.938, de 31.8.1981, chamada Política Nacional do Meio Ambiente; e art. $6^{050}$, da Lei n. $7.347 / 85^{51}$ ), e a Lei n. 10.650 , de 16.4.2003, disciplina a chamada Lei do Direito à Informação Ambiental, dispondo sobre o acesso público aos dados e informações existentes nos órgãos e entidades integrantes do Sistema Nacional do Meio Ambiente - Sisnama ${ }^{52}$, reforçando, com isso, a responsabilidade solidária entre Poder Público e coletividade na prevenção, preservação e promoção da qualidade dos bens ecológicos.

A evolução do Estado Socioambiental de Direito compreende, assim, uma democracia que vai além das urnas, e o direito à informação ambiental significa em suma a possibilidade do controle social sobre as decisões administrativas do Poder Público no que diz respeito a tudo que concerne o ambiente $\mathrm{e}$ que, como somos integrantes do ambiente e vivemos da interação com ele, atinge reflexamente a todos nós ${ }^{53}$. Estreitamente relacionada à dignidade humana, na perspectiva que a qualidade do ambiente é vital para a sadia qualidade de vida, para as presentes e futuras gerações, a sustentabilidade da democracia consiste em condição e qualidade de informação dos cidadãos, do que se exprime que a sustentabilidade ambiental é diretamente conectada ao acesso à informação ${ }^{54}$.

\footnotetext{
${ }^{50}$ Lei n. 7.347/85, art. $6^{\circ}$ - Qualquer pessoa poderá e o servidor público deverá provocar a iniciativa do Ministério Público, ministrando-lhe informações sobre fatos que constituam objeto da ação civil e indicando-lhe os elementos de convicção.

${ }^{51}$ BARROS, Lucivaldo Vasconcelos. Direito à informação socioambiental e desenvolvimento sustentável. Revista de Direito Ambiental. Ano 12, n. 45, jan.-mar.2007, p. 167-183, p. 179.

${ }^{52}$ Lei n. 10.650, de 16.4.2003, art. $2^{\circ}$ - Os órgãos e entidades da Administração Pública, direta, indireta e fundacional, integrantes do Sisnama, ficam obrigados a permitir o acesso público aos documentos, expedientes e processos administrativos que tratem de matéria ambiental e a fornecer todas as informações ambientais que estejam sob sua guarda, em meio escrito, visual, sonoro ou eletrônico, especialmente as relativas a:

I - qualidade do meio ambiente;

II - políticas, planos e programas potencialmente causadores de impacto ambiental;

III - resultados de monitoramento e auditoria nos sistemas de controle de poluição e de atividades potencialmente poluidoras, bem como de planos e ações de recuperação de áreas degradadas;

IV - acidentes, situações de risco ou de emergência ambientais;

$\mathrm{V}$ - emissões de efluentes líquidos e gasosos, e produção de resíduos sólidos; VI - substâncias tóxicas e perigosas;

VII - diversidade biológica;

VIII - organismos geneticamente modificados

${ }^{53}$ SILVA, Brisa Arnoud da. Do Estado Liberal para Socioambiental de Direito: o caminho para o desenvolvimento sustentável. In: SOUZA, Maria Claudia da Silva Antunes de; ARMADA, Charles Alexandre Souza (Org.). Teoria jurídica e Transnacionalidade. vol. II, 2014, p. 130-152, p. 132. Disponível em: <http://www.univali.br/ppcj/ebook>. Acesso em: 21 jul.2014.

${ }^{54}$ GOMES, Carla Amado. A caminho de uma ecocidadania: notas sobre o
}

Os princípios do Direito Ambiental, estabelecidos com o intuito de auxiliar as leis e conciliar o desenvolvimento à qualidade de vida, emergem frente as novas necessidades entre a economia e preservação do ambiente, consolidando as regras emanadas na Declaração da Conferência da Organização das Nações Unidas sobre Meio Ambiente Humano, ocorrida em Estocolmo em 1972, na Política Nacional de Meio Ambiente, da CRFB/88, Conferência sobre Meio Ambiente e Desenvolvimento, em 1992 - ECO 92, no Rio de Janeiro. Dentre os princípios norteadores, destaca-se o Princípio 10 da Declaração do Rio de Janeiro/92 que inter-relaciona os princípios da Informação, da Participação e Cooperação, que interagem e atuam como conjunto de instrumentos para materializar o Estado Socioambiental de Direito ${ }^{55}$.

A Convenção da Comissão Econômica para a Europa das Nações Unidas (CEE/ONU) sobre Acesso à Informação, Participação do Público no Processo de Tomada de Decisão e Acesso à Justiça em Matéria de Ambiental foi adotada em 25.6.1998, na cidade dinamarquesa de Aarhus, durante a 4 a Conferência Ministerial “Ambiente para a Europa” e entrou em vigor em 30.10.2001, concluído o processo de ratificação por 16 países membros da CEE/ONU e pela União Europeia, conforme previsto no art. $20^{56}$.

Considerada o primeiro "instrumento universal de democratização das decisões sobre o ambiente" ${ }^{\text {, }}$, é considerada um marco no desenvolvimento procedimental do Direito Ambiental com a expansão da noção de democracia para uma aberta e transparente

\footnotetext{
direito à informação ambiental. Revista de Direito Ambiental. Ano 12, n. 45, jan.-mar.2007, p. 259-272, p. 261.

${ }^{55}$ Princípio 10- O melhor modo de tratar as questões ambientais é com a participação de todos os cidadãos interessados, em vários níveis. No plano nacional, toda pessoa deverá ter acesso adequado à informação sobre o ambiente de que dispõem as autoridades públicas, incluída a informação sobre os materiais e as atividades que oferecem perigo em suas comunidades, assim como a oportunidade de participar dos processos de adoção de decisões. Os Estados deverão facilitar e fomentar a sensibilização e a participação do público, colocando a informação à disposição de todos. Deverá ser proporcionado acesso efetivo aos procedimentos judiciais e administrativos, entre os quais o ressarcimento de danos e os recursos pertinentes. Disponível em: <http://veja.abril.com.br/complementos-materias/rio+20-widgets/pdf/ declaracao-do-rio-de-janeiro-sobre-meio-ambiente-desenvolvimento.pdf $>$. Acesso em: 4 out. 2014 .

${ }^{56}$ Convenção de Aarhus. Agência Portuguesa do Ambiente. Disponível em: <http://www.apambiente.pt/index.php?ref=16\&subref=142\&sub2re$\mathrm{f}=726 \&$ sub3ref $=727>$. Acesso em: 20 set. 2014.

${ }^{57}$ GOMES, Carla Amado. A caminho de uma ecocidadania: notas sobre o direito à informação ambiental. Revista de Direito Ambiental. Ano 12, n. 45, jan.-mar.2007, p. 259-272, p. 267.
} 
sociedade. Em seu preâmbulo, reconhece que o ambiente é essencial para o bem-estar dos indivíduos e a satisfação dos direitos humanos fundamentais, incluindo o próprio direito à vida; que todos os indivíduos têm o direito de viver num ambiente propício à sua saúde e bem-estar, e o dever de proteger e melhorar o ambiente em benefício das gerações presentes e futuras; que para poderem exercer esse direito e cumprir esse dever, os cidadãos devem ter acesso à informação, poder participar no processo de tomada de decisões e ter acesso à justiça no domínio do ambiente; e que a melhoria do acesso à informação e da participação pública no processo de tomada de decisões aumenta a qualidade das decisões, possibilitando manifestar as suas preocupações e permitindo às autoridades públicas levar em consideração essas preocupações, visto como uma contribuição para proteção de um direito substantivo implícito ao ambiente decente ${ }^{58}$.

Os três pilares que a Convenção de Aarhus concebe e assenta, da informação para todos (arts. $4^{\circ}$ e $5^{\circ}$ ), participação de todos (arts. $6^{\circ}, 7^{\circ}$ e $8^{\circ}$ ), e acesso à justiça ao público interessado (art. $9^{\circ}$ ), são elementos essenciais para uma participação democrática bem como um meio de tornar a proteção ambiental mais eficiente.

Na Convenção de Aarhus o acesso à informação abrange uma gama de dados relativas ao estado do ambiente, fontes de males ambientais, medidas para melhorar o ambiente e consequências dos males ambientais. $\mathrm{O}$ acesso à informação é concedido a todos independente de um interesse. No entanto, além do acesso passivo de informação, a convenção também obriga os Estados signatários a recolher e divulgar informações ambientais, incluindo informações sobre ameaças iminentes para a saúde e o ambiente ${ }^{59}$, em que não se admite a recusa de informação sob alegação de confidencialidade comercial e industrial, determinado pela Convenção na alínea $d$ do n. 4 do art. $4^{\circ}$ que toda informação relativa à emissão de poluente relevante para efeito da proteção do ambiente

\footnotetext{
${ }^{58}$ Convenção sobre Acesso à Informação, Participação do Público no Processo de Tomada de Decisão e Acesso à Justiça em Matéria de Ambiente. Disponível em: <http://www.unece.org/fileadmin/DAM/env/pp/EU\%20 texts/conventioninportogese.pdf $>$. Acesso em: 20 set. 2014.

${ }^{59}$ REHBINDER, Eckard. Democracy, acessto justice andenvironmentatthe internacional level. Disponível em: <http://www.cidce.org/pdf/livre\%20rio/ rapports\%20g\%C3\%A9n\%C3\%A9raux/rehbinder.pdf>. Acesso em: 28 ago. 2014.
}

é de divulgação obrigatória. Esta disposição transparece a primazia da saúde e do ambiente em face dos interesses econômicos ${ }^{60}$.

Assim, a visualização e análise do cenário de impacto socioambiental e sua repercussão precisa de ampla variedade de informações socioambientais, a fim de contextualizá-las para construir o conhecimento de acordo com a realidade. A disseminação da informação socioambiental pode incitar a participação pública ao articular os eventos sociais, econômicos e políticos e as consequências e efeitos que atingem a população e o ambiente, de modo que potencializa e capacita a mudança comportamental em relação às questões que afetam a sociedade como um todo. Por isso a importância/receio dos poderes dominantes e dopróprio Poder Público em fornecer e transmitir informações sobre a qualidade do ambiente ou potencial risco ambiental. Acontece que a esfera pública também usa a informação como instrumento de manipulação política ${ }^{61}$, numa campanha que estimula a população a essa postura imediatista de consumo diante do mercado cada vez mais voltado aos interesses econômicos ${ }^{62}$.

Na prática, assegurar o acesso a informação, especialmente às informações ambientais concernentes aos efeitos da Sociedade de Risco, encontra muitas dificuldades, e os Interesses políticos e econômicos se afirmam como verdadeiras barreiras e a falta de transparência na comunicação passa sutilmente despercebida num primeiro olhar, mas atingem a todos nós ${ }^{63}$.

\section{$4 \mathrm{O}$ direito à informação do consumidor}

Os efeitos da Sociedade da Informação se refletem sobre toda multidão de consumidores ${ }^{64}$, e o direito à informação também é tratado no Código de

\footnotetext{
${ }^{60}$ GOMES, Carla Amado. A caminho de uma ecocidadania: notas sobre o direito à informação ambiental. Revista de Direito Ambiental. Ano 12, n. 45, jan.-mar.2007, p. 259-272, p. 271

${ }^{61}$ MACHADO, Paulo Affonso Leme. Direito à informação e meio ambiente. São Paulo: Malheiros, 2006, p. 30

${ }^{62}$ BARROS, Lucivaldo Vasconcelos. Direito à informação socioambiental e desenvolvimento sustentável. Revista de Direito Ambiental. Ano 12, n. 45 , jan.-mar.2007, p. 167-183, p. 168- 170.

${ }^{63}$ BARROS, Lucivaldo Vasconcelos. Direito à informação socioambiental e desenvolvimento sustentável. Revista de Direito Ambiental. Ano 12, n. 45, jan.-mar.2007, p. 167-183, p. 170.

${ }^{64}$ LISBOA, Roberto Senise. Direito na sociedade da informação. Revista dos Tribunais. Ano. 95, vol. 847, mai.-2006, p. 78-95, p. 92
} 
Defesa do Consumidor - $\mathrm{CDC}^{65}$, em diversos títulos, capítulos e seções $^{66}$, não obstante, não dirige a informação apenas no sentido de estimular desejos e necessidades na relação de consumo, tampouco em fornecê-la em velocidade e quantidades inimagináveis, mas determinando e esclarecendo a obrigação legal dos fornecedores de prover informação e usar a publicidade de forma idônea, adequada e clara ${ }^{67}$ sobre os produtos e serviços disponibilizados ao consumo.

$\mathrm{O}$ CDC interage com diferentes ramos do Direito, como o Ambiental, Administrativo, Civil, Processual Civil, Comercial, Constitucional, Internacional, Penal, Trabalhista, Tributário, com o objetivo de disciplinar a proteção e defesa do consumidor, preconizando o respeito à saúde, dignidade e segurança humana com o propósito de bem-estar. A transparência e/à harmonia nas relações de consumo, envolve o comprometimento dos sistemas capitalistas com a proteção ambiental, visto que a CRFB/88 se comprometeu a conciliar tanto o desenvolvimento econômico do país, quanto à preservação do ambiente no desempenho do desenvolvimento sustentável, nos art. $3^{\circ}$, inc. II, o art. 170 , inc. VI e art. $225^{68}$. Dessa forma, segundo o legislador constituinte brasileiro a consecução da melhoria da qualidade de vida precisa da comunhão de esforços entre iniciativa privada, Poder Público, e sociedade civil, numa responsabilidade solidária orientada pelo Princípio da Sustentabilidade $^{69}$.

\footnotetext{
${ }^{65} \mathrm{~A}$ CRFB/88 estabeleceu o direito do consumidor nos arts. $5^{\circ}$, inc. XXXII e 170, inc. V, disciplinado pela Lei n. 8.078, de 11.11.1990, chamado Código de Defesa do Consumidor.

${ }^{66} \mathrm{O}$ direito à informação no CDC, à exceção da Seção VI, que trata especificamente Dos Bancos de Dados e Cadastros de Consumidores, é apontado no art. $4^{\circ}$, inc. IV; art. $6^{\circ}$, inc. III; art. $8^{\circ}$, caput e parágrafo único; art. $9^{\circ}$; art. 12; art. 14 ; art. 31 ; art. $37, \S 1^{\circ}$; art. $55, \S 1^{\circ}$ e $\$ 4^{\circ}$; art. 66 ; e art. 106, inc. IV. ${ }^{67}$ MACHADO, Paulo Affonso Leme. Direito ambiental brasileiro. 12. ed. p.78. São Paulo: Malheiros, 2004, p. 263, p. 200: “O termo 'publicidade’ pode ser entendido em dois sentidos: 'publicidade’ como tornar público algo, não se mantendo em segredo o fato; e 'publicidade' como propaganda ou técnica de obter a aceitação do público. Nesse último sentido o termo foi empregado no Código do Consumidor. Antônio Herman de Vasconcelos e Benjamin afirma: 'O Código não obriga o fornecedor a anunciar. A publicidade, por esse prisma, em não sendo dever, é direito, só que direito exercitável à conta e risco do anunciante. O legislador, em tal matéria, não sanciona a carência de publicidade, mas somente a existência de publicidade que traduza uma má ou insuficiente informação. Não há no Código nenhuma regra que imponha um dever de anunciar, a priori, dirigido ao consumidor".

${ }^{68} \mathrm{CRFB} / 88$ - Art. 5º XXXII- o Estado promoverá, na forma da lei, a defesa do consumidor; Art. 170. A ordem econômica, fundada na valorização do trabalho humano e na livre iniciativa, tem por fim assegurar a todos existência digna, conforme os ditames da justiça social, observados os seguintes princípios: V- defesa do consumidor; VI- defesa do meio ambiente (...);

${ }^{69}$ FREITAS, Juarez. Sustentabilidade: direito ao futuro. $2^{\circ}$ ed. Belo Horizonte: Fórum, 2012. p.41.
}

Portanto, o fornecedor de produtos e serviços precisa atentar que a informação dirigida ao consumidor deve conter especificação correta de quantidade, características, composição, qualidade, tributos incidentes, preço, garantia, prazos de validade, origem, riscos..., assegurando que observados esses requisitos não acarretarão riscos à saúde ou segurança dos consumidores, além daqueles considerados dentro do padrão de normalidade, obedecendo critérios de precisão, integralidade e veracidade. A precisão refere-se ao canal de comunicação utilizado e o conteúdo da informação, em que o meio escolhido para disseminar informação do produto/serviço deve ser apropriado ao seu público-alvo, e apresentada de modo que a organização visual e textual da informação permitam sua interpretação com nitidez e exatidão, mencionando sua composição, riscos e periculosidade. A integralidade concerne que a informação não pode ser omissa ou imprecisa, mas, literalmente, inteira e completa, e para esse fim o CDC certificou que não se admitem "meias verdades" e a omissão sobre dado essencial do produto ou serviço, é considerada publicidade enganosa ${ }^{70}$. A veracidade equivale à informação certa e correta quanto as características fidedignas do produto e do serviço, em relação a composição, conteúdo, preço, prazos, garantias e riscos.

Com isso, os deveres de informação expressam a essencialidade do princípio da transparência e da boa-fé (objetiva) contratual nas relações de consumo $^{71}$, dispostos no art. 4 e $31^{72}$ do CDC. O princípio da boa-fé também é previsto na Lei n. 10.406, de 10.01.2002, o Código Civil - CC/2002, nos arts. 113 e $422^{73}$ e vem reforçar, o que já era previsto no CDC.

\footnotetext{
${ }^{70}$ CDC, Art. 36; art. 37, $\$ 1^{\circ}$ e $\$ 3^{\circ}$; art. 66; art. 67.

${ }^{71}$ KUNISAWA, Viviane Yumy M. O direito de informação do consumidor e a rotulagem dos alimentos geneticamente modificados. Revista do Direito do Consumidor. n. 53, jan.- mar., São Paulo: Editora Revista dos Tribunais, 2005. p. 135-150, p. 137.

${ }^{72}$ CDC, art. $4^{\circ}$ - A Política Nacional das Relações de Consumo tem por objetivo o atendimento das necessidades dos consumidores, o respeito à sua dignidade, saúde e segurança, a proteção de seus interesses econômicos, a melhoria da sua qualidade de vida, bem como a transparência e harmonia das relações de consumo, atendidos os seguintes princípios: IV - educação e informação de fornecedores e consumidores, quanto aos seus direitos e deveres, com vistas à melhoria do mercado de consumo; art. 31- A oferta e apresentação de produtos ou serviços devem assegurar informações corretas, claras, precisas, ostensivas e em língua portuguesa sobre suas características, qualidades, quantidade, composição, preço, garantia, prazos de validade e origem, entre outros dados, bem como sobre os riscos que apresentam à saúde e segurança dos consumidores.

${ }^{73}$ CC/2002, art. 113- Os negócios jurídicos devem ser interpretados
} 
Estes dois dispositivos legais devem ser observados em todos os negócios e contratos em geral ${ }^{74}$.

Com a expansão do uso de mensagens ambientais e da maquiagem verde na publicidade institucional e de produtos e serviços, o Conselho Nacional de Autorregulamentação de Publicidade - CONAR se pronunciou em relação ao papel da publicidade. O CONAR é uma organização não governamental que tem como missão evitar e prevenir a publicidade enganosa ou abusiva ${ }^{75}$.

Com esse fim, acrescentou no Código Brasileiro de Autorregulamentação de Publicidade o parágrafo único do art. $36^{76}$, Seção 10 , e o Anexo U, que visam especificamente combater o greenwashing na transmissão de informação, estabelecendo princípios práticos, em conformidade com a legislação nacional, que orientam à veracidade, exatidão, pertinência e relevância das informações. Esses princípios visam impedir informações falsas, exageradas, ambíguas sobre produtos e serviços que se dizem ecologicamente corretos de modo que o apelo ambiental veiculado seja comprovável.

Como aponta o Instituto Akatu, a publicidade é o principal meio de informação sobre produtos e serviços de que dispõe o consumidor ${ }^{77}$, por isso é importante considerar a responsabilidade socioam-

conforme a boa-fé e os usos do lugar de sua celebração; art. 422- Os contratantes são obrigados a guardar, assim na conclusão do contrato, como em sua execução, os princípios da probidade e da boa-fé.

${ }^{74}$ KUNISAWA, Viviane Yumy M. O direito de informação do consumidor e a rotulagem dos alimentos geneticamente modificados. Revista do Direito do Consumidor. n. 53, jan.- mar., São Paulo: Editora Revista dos Tribunais, 2005. p. 135-150, P. 139-140.

${ }^{75}$ Conselho Nacional de Autorregulamentação de Publicidade. Disponível em: <http://www.conar.org.br/>. Acesso em: 6 out. 2014.

${ }^{76}$ Código Brasileiro de Autorregulamentação de Publicidade, art. 36- A publicidade deverá refletir as preocupações de toda a humanidade com os problemas relacionados com a qualidade de vida e a proteção do meio ambiente; assim, serão vigorosamente combatidos os anúncios que, direta ou indiretamente, estimulem: 1. a poluição do ar, das águas, das matas e dos demais recursos naturais; 2 . a poluição do meio ambiente urbano; 3 . a depredação da fauna, da flora e dos demais recursos naturais; 4. a poluição visual dos campos e das cidades; 5. a poluição sonora; 6. o desperdício de recursos naturais. Parágrafo único: Considerando a crescente utilização de informações e indicativos ambientais na publicidade institucional e de produtos e serviços, serão atendidos os seguintes princípios: veracidade - as informações ambientais devem ser verdadeiras e passíveis de verificação e comprovação; exatidão - as informações ambientais devem ser exatas e precisas, não cabendo informações genéricas e vagas; pertinência - as informações ambientais veiculadas devem ter relação com os processos de produção e comercialização dos produtos e serviços anunciados; relevância - o benefício ambiental salientado deverá ser significativo em termos do impacto total do produto e do serviço sobre o meio ambiente, em todo seu ciclo de vida, ou seja, na sua produção, uso e descarte.

${ }^{77}$ Instituto Akatu. Disponível em: <http://www.akatu.org.br/>. Acesso em: 6 out. 2014. biental da publicidade na Sociedade da Informação, porque exercem importante influência sob o sujeito no espaço público, por meio da seleção das informações que cercam o imaginário ideológico na representação da livre escolha ${ }^{78}$.

\section{A importância da informação e rotulagem no consumo de alimentos transgênicos}

As interferências humanas sob o ambiente refletem diretamente na vida, saúde e bem-estar de todos, e nesse contexto complexo em que se admite e reconhece apresença e comercialização de transgênicos e agrotóxicos, a garantia do direito à informação torna-se essencial para o esclarecimento sobre possíveis ameaças à saúde e a vida.

A saúde também consta no rol dos direitos fundamentais sociais nos arts. $6^{079}, 196$ e $197^{80}$, direito de todos e dever do Estado de assegurar, por meio de políticas públicas que visem à redução do risco de doenças e o acesso universal e igualitário às ações e serviços para sua promoção, proteção e recuperação, percebendo a dupla perspectiva do dever do Estado, de abster-se de praticar atos que prejudiquem terceiros, e de implementar o direito social.

$\mathrm{O}$ art. 200 da CRFB/88 instituiu a competência do Sistema Único de Saúde - SUS de controlar e fiscalizar procedimentos, produtos e substâncias de interesse para a saúde e participar da produção de medicamentos, equipamentos, imunobiológicos, hemoderivados e outros insumos (inc. I); executar as ações de vigilância sanitária e epidemiológica, bem como as de saúde do trabalhador (inc. II); fiscalizar e inspecionar alimentos, bebidas e águas para consumo humano, compreendendo o controle de seu teor nutricional (inc. VI); participar do controle e fiscalização da produção, transporte, guarda e utilização de

\footnotetext{
78 SILVA, Telma Domingues da. Educação ambiental: a educação para o consumo na sociedade da informação. Linguagem em (Dis)curso [online], Tubarão, SC, v. 11, n. 3, p. 563-584, set./dez. 2011, p. 568. Disponível em: <http://www.scielo.br/scielo.php?script=sci_arttext\&pi$\mathrm{d}=\mathrm{S} 1518-76322011000300006 \& \operatorname{lng}=\mathrm{en} \& \mathrm{nrm}=\mathrm{iso}>$. Acesso em: 11 set. 2014

${ }^{79} \mathrm{CRFB} / 88$, art. $6^{\circ}$ - São direitos sociais a educação, a saúde, a alimentação, o trabalho, a moradia, o lazer, a segurança, a previdência social, a proteção à maternidade e à infância, a assistência aos desamparados, na forma desta Constituição. (Redação dada pela Emenda Constitucional nº 64, de 2010)

${ }^{80} \mathrm{CRFB} / 88$, art. 197- São de relevância pública as ações e serviços de saúde, cabendo ao Poder Público dispor, nos termos da lei, sobre sua regulamentação, fiscalização e controle, devendo sua execução ser feita diretamente ou através de terceiros e, também, por pessoa física ou jurídica de direito privado.
} 
substâncias e produtos psicoativos, tóxicos e radioativos (inc. VII), e colaborar na proteção do ambiente, nele também compreendido o do trabalho (inc. VIII).

A alimentação adequada foi consagrada recentemente no rol dos Direitos Sociais por meio da Emenda Constitucional 64 de 2010, já preconizada pela Lei n. 11.346, de 15.11.2006, que criou o Sistema Nacional de Segurança Alimentar e Nutricional - SISAN com objetivo de assegurar o direito fundamental à alimentação adequada (art. $2^{\circ}$ da Lei n. 11. 346/2006), integrando a concepção do mínimo existencial indispensável à sadia qualidade de vida.

Nesse sentido, os direitos à saúde e à alimentação vinculam-se intrinsecamente ao direito ao ambiente ecologicamente equilibrado, porque fonte de alimentos, essencial à sadia qualidade de vida, intimamente relacionado à dignidade. A dignidade humana, como num círculo, depende do mínimo existencial ecológico, com a garantia de alimentação, saúde, educação, moradia e ambiente equilibrado ${ }^{81}$.

Dando enfoque aos institutos do direito constitucional sobre as regras de comunicação social, o $\S$ $4^{\mathrm{o}}$ do art. 220 determina que a propaganda comercial de tabaco, bebidas alcoólicas, agrotóxicos, medicamentos e terapias estará sujeita a restrições legais e conterá, sempre que necessário, advertência sobre os malefícios decorrentes de seu uso, assim como as criações científicas, artísticas e principalmente tecnológicas, estabelecendo meios legais que garantam à pessoa e à família a possibilidade de se defenderem da propaganda de produtos, práticas e serviços que possam ser nocivos à saúde e ao ambiente $\left(\S 3^{\circ}\right.$, inc. II do art. 220 $)^{82}$, e a capacidade de manipulação genética, que cria os Organismos Geneticamente Modificados - OGMs, é um dos polêmicos temas desenvolvidos pelo avanço científico.

Após o fim das grandes guerras, a indústria química precisava dar novo propósito à infraestrutura e o arsenal bélico desenvolvidos, e em virtude da sua potencialidade destrutiva herbicida, pesticida e inseticida voltou-se à agricultura. A proposta da Revolução Verde, a política agrícola estadunidense de

\footnotetext{
${ }^{81}$ SOARES, Ricardo Maurício Freire. Direito, justiça e princípios constitucionais. Salvador: Jus Podivm, 2008, p. 77-92.

${ }^{82}$ FIORILLO, Celso Antonio Pacheco. Fundamentos constitucionais do meio @mbientedigit@l na sociedade da informação. In:Paesani, Liliana. O direito na sociedade da informação III: A evolução do direito digital, v.3, Atlas, 2013, p. 17.
}

expansão de mercado, teve seu estopim estimulada pela modernização das técnicas agrícolas, a mecanização na lavoura, a utilização de produtos químicos, e provocou o aumento da produção em larga escala, difundida pela promessa de salvação da fome no mundo no final da década de $60^{83}$. A Revolução Verde prometia incrementar a produtividade mundial de alimentos com técnicas modernas de uso intensivo de insumos químicos e sementes híbridas, progredindo o rendimento das safras a ponto de acabar com o problema da fome, mas em pouco tempo se revelaram os efeitos nocivos dessa estratégia. Em 1962 Rachel Carson publicou o livro "Primavera Silenciosa" denunciando o perigo do uso indiscriminado de produtos químicos e as consequências maléficas dos tóxicos na contaminação e envenenamento do homem e do ambiente, como o desenvolvimento de cânceres, malformações ${ }^{84}$ e incapacidades ${ }^{85}$.

Ainda hoje, as indústrias químicas e sistemas especializados procuram desmerecer as ameaças e efeitos que retornam das ações e comportamentos, evidenciados desde aquele tempo por Carson, num esforço de retardar leis de controle ambiental e persuadir a população dos benefícios dos transgênicos e agrotóxicos para a prosperidade agrícola, minimizando os riscos delatados, denotando a irresponsabilidade organizada do Poder Público e interesses econômicos ${ }^{86}$.

Paulo Afonso Brum Vaz observa que o modelo agrícola difundido pela Revolução Verde não serviu para resolver o problema da fome, mas para enriquecer grandes empresas, mensurando os extensos campos verdes de plantações e o vultoso número de pessoas passando fome ou com alimentação inadequada: "São produzidas e exportadas milhares

\footnotetext{
${ }^{83}$ VAZ, Paulo Afonso Brum. O direito ambiental e os agrotóxicos: responsabilidade civil, penal e administrativa. Porto Alegre: Livraria do Advogado, 2006, p. 21-22-27.

84 Disponível em: <http://www.mst.org.br/Aumenta-incidencia-de-cancer-e-bebes-malformados-em-regioes-de-producao-de-soja-transgenica> Acesso em: 17 out. 2014.

${ }^{85}$ FERREIRA, HelineSivini; FERREIRA, Maria Leonor Paes Cavalcanti. Registro e importação de agrotóxicos: não seria dever do Poder Público controlar as atividades que envolvem substâncias capazes de causar danos à vida, à qualidade de vida e ao meio ambiente? In: FERREIRA, HelineSivini; FERREIRA, Maria Leonor Paes Cavalcanti (Org.). Dano ambiental na sociedade de risco. São Paulo: Saraiva, 2012. p. 185-212, p. 188.

${ }^{86}$ ACSELRAD, Henri. A irresponsabilidade ambiental organizada. Disponível em: <http://www.justicaambiental.org.br/v2/admin/anexos/acervo/17_030408_artigo_irresposabilidade_ambiental_organizada_henri. pdf>. Acesso em: 13 jan. 2015.
} 
de toneladas de grãos, usadas até para o fabrico de ração animal em outros países. Enquanto isso, falta alimento para consumo humano interno!"87.

Pelas mesmas razões, Vandana Shiva torna público os efeitos negativos da mentalidade de monocultura da Revolução Verde, da silvicultura e agricultura científica no contexto indiano, que exclui as funções de produção de alimento da floresta e destrói sua diversidade, vista como "erva daninha", bem como também devasta espécies que podem ser utilizadas como alimento, porque não são úteis do ponto de vista do mercado, delatando que a produção de alimentos nunca foi o interesse, substituindo culturas consideradas "marginais", "inferiores" e "de má qualidade" pelo paradigma exclusivista da madeira para comércio e indústria ${ }^{88}$.

A política da Revolução Verde criou um modelo de desenvolvimento em que a agricultura moderna gira em torno de mercadoria e não de subsistência, que irrompe num retrocesso ecológico que desencadeia graves problemas socioambientais. Mas na atualidade, a articulação do Direito Ambiental e sua expressão intrinsecamente velada à dignidade humana, relacionado a todos demais Direitos Fundamentais do Estado Socioambiental de Direito, permite questionar os artifícios da ordem econômica.

No Brasil a Lei n. 11.105 de 24.3.2005, chamada Lei de Biossegurança, estabelece normas de segurança e mecanismos de fiscalização sobre a construção, o cultivo, a produção, a manipulação, o transporte, a transferência, a importação, a exportação, o armazenamento, a pesquisa, a comercialização, o consumo, a liberação no ambiente e o descarte de OGMs e seus derivados, tendo como diretrizes o estímulo ao avanço científico na área de biossegurança e biotecnologia, a proteção à vida e à saúde humana, animal e vegetal, e a observância do princípio da precaução para a proteção do ambiente (art. $1^{\circ}$ ).

$\mathrm{O}$ art. $3^{\circ}$, inc. $\mathrm{V}$ conceitua os OGMs como organismos cujo material genético - $\mathrm{ADN} / \mathrm{ARN}^{89}$

\footnotetext{
${ }^{87}$ VAZ, Paulo Afonso Brum. O direito ambiental e os agrotóxicos: responsabilidade civil, penal e administrativa. Porto Alegre: Livraria do Advogado, 2006, p. 27-28.

${ }^{88}$ SHIVA, Vandana. Monoculturas da mente: perspectivas da biodiversidade e da biotecnologia. Trad. Dinah de Abreu Azevedo. São Paulo: Editora Gaia, 2003, p. 39-63.

${ }^{89} \mathrm{O}$ mesmo dispositivo conceitua no seu inciso II, o ADN - ácido desoxirribonucleico, e $\mathrm{ADN}$ - ácido ribonucleico como material genético que contém informações determinantes dos caracteres hereditários transmissíveis à descendência;
}

tenha sido modificado por qualquer técnica de engenharia genética.

Para fins de esclarecimento, o OGM é manipulado em laboratório e de alguma forma tem seu genoma alterado. O transgênico diferencia do OGM especificamente porque sofre a técnica de inserção de um trecho de DNA de outra espécie. A formação de um transgênico significa uma mistura artificial criada pelo homem e pela ciência e um gene adulterado, no cruzamento de espécies, gêneros ou até reinos diferentes através de técnicas que modificam o DNA da célula. A inserção de um gene característico exógeno em outro resulta num organismo híbrido, o transgênico ${ }^{90}$. Logo, "todo transgênico é um tipo de OGM, mas nem todo OGM é um transgênico"91. Alimentos geneticamente modificados são aqueles que contêm ou são produzidos a partir de $\mathrm{OGMs}^{92}$. Já os alimentos transgênicos passam por uma transformação na sua estrutura de DNA, por intermédio da engenharia genética, em que alguns de seus genes são substituídos por genes de outros organismos a fim de que sejam transmitidas características distintas das que possuíam originalmente ${ }^{93}$.

Sob o prisma da Sociedade de Risco, a agrobiotecnolgia se promove diante do exponencial crescimento populacional mundial e a preocupação em satisfazer as necessidades alimentares no futuro próximo. Comovantagensaos OGMs, numa estratégia baseada em criar variedades resistentes a pestes minorando perdas, alegam maior produtividade a menor custo, melhoramento de qualidade nutricional e benefícios para a saúde e ambiente com a redução do uso de agrotóxicos ${ }^{94}$. Os argumentos contrários aos transgênicos referem-se à potencialização dos efeitos das substâncias tóxicas, aumento das

\footnotetext{
${ }^{90}$ RODRIGUES, Melissa Cachoni; ARANTES, Olivia Marcia Nagy. Direito ambiental e biotecnologia: uma abordagem sobre os transgênicos sociais. $1^{\text {a }}$ ed. (ano 2004) 2a tir. Curitiba: Juruá, 2005, p. 24.

${ }^{91}$ Centro de Genética Molecular: Centro de Formação Genética e certificação molecular. Disponível em: <http://www.cgm.icb.ufmg.br/oquesao.php>. Acesso em: 7 out. 2014.

${ }^{92}$ KUNISAWA, Viviane Yumy M. O direito de informação do consumidor e a rotulagem dos alimentos geneticamente modificados. Revista do Direito do Consumidor. n. 53, jan.-- mar., São Paulo: Editora Revista dos Tribunais, 2005. p. 135-150. p. 135.

${ }^{93}$ FISCHER, Karla Ferreira de Camargo. A problemática dos alimentos transgênicos e o direito do consumidor à informação. Cadernos da Escola de Direito e Relações Internacionais das Faculdades do Brasil. Curitiba, v. 1, n. 1, mar.-ago. 2002, p. 119-139, p. 120.

${ }^{94}$ RODRIGUES, Melissa Cachoni; ARANTES, Olivia Marcia Nagy. Direito ambiental e biotecnologia: uma abordagem sobre os transgênicos sociais. $1^{\mathrm{a}}$ ed. (ano 2004) 2a tir. Curitiba: Juruá, 2005, p. 34.
} 
alergias pela transferência de propriedade alergênica de uma espécie à outra que até então estava livre dela, desenvolvimento de resistência bacteriana e antibióticos, alteração do nível nutricional dos alimentos, aparecimento de superpragas, superervas daninhas ou plantas superinvasoras ${ }^{95}$, impossibilidade de controle sobre a natureza com perigo de extinção de espécies e consequente alteração do equilíbrio dos ecossistemas, e monopólio econômico pelas grandes empresas multinacionais detentoras da biotecnologia e consequente dependência dos agricultores na compra dessas sementes ${ }^{96}$.

Não se pretende aqui adotar posicionamento a respeito do uso dos transgênicos ou esgotar benefícios e malefícios para o ambiente e para o homem, contudo, salientar o direito do cidadão consumidor ser informado se o produto ou serviço é, contem ou é feito a partir de OGMs e transgênicos ${ }^{97}$, aliado ao direito fundamental da informação ambiental ${ }^{98}$, o direito do consumidor à correta informação ${ }^{99}$, e a própria Lei de Biossegurança, que dispõe no art. 40 que os alimentos e ingredientes alimentares destinados ao consumo humano e/ou animal que contenham ou sejam produzidos a partir de OGM deverão conter informação no seu respectivo rótulo ${ }^{100}$.

Sob o prisma da Sociedade da Informação, pululam notícias de produtos suspeitos de conter

\footnotetext{
${ }_{95}$ BÁRCENA, Alicia et al. Los transgénicos en América Latina y el Caribe: un debate abierto. Santiago de Chile: Naciones Unidas, 2004, p. 64.

96 Nesse sentido: RODRIGUES, Melissa Cachoni; ARANTES, Olivia Marcia Nagy. Direito ambiental e biotecnologia: uma abordagem sobre os transgênicos sociais. $1^{\text {a }}$ ed. (ano 2004) 2a tir. Curitiba: Juruá, 2005, p. 34; LUTZENBERGER, José Antônio. O absurdo da agricultura. Estudos Avançados 15, 43, 2001. Disponível: <http://www.scielo.br/pdf/ea/v15n43/ v15n43a07.pdf>. Acesso em: 7 out. 2014; Ministério do Meio Ambiente. Riscos. Disponível em: <http://www.mma.gov.br/clima/item/7511-riscos>. Acesso em: 11 out. 2014; SHIVA, Vandana. Monoculturas da mente: perspectivas da biodiversidade e da biotecnologia. Trad. Dinah de Abreu Azevedo. São Paulo: Editora Gaia, 2003: p. 41- As estratégias da engenharia genética voltadas para a resistência e que estão destruindo espécies de plantas úteis também podem acabar criando superervas daninhas. (...) as variedades cultivadas interagem geneticamente há séculos e se cruzam livremente, produzindo novas variedades. Os genes da tolerância a herbicidas que os engenheiros genéticos estão tentando introduzir na agricultura podem ser transferidos para as ervas-daninhas das proximidades em consequência de um cruzamento genético que ocorre naturalmente.

${ }^{97}$ KUNISAWA, Viviane Yumy M. O direito de informação do consumidor e a rotulagem dos alimentos geneticamente modificados. Revista do Direito do Consumidor. n. 53, jan.- mar., São Paulo: Editora Revista dos Tribunais, 2005. p. $135-150$, p. 136

${ }^{98} \mathrm{CRFB} / 88$, art. $5^{\circ}$, incs. XIV, XXXIII; art. 225, caput e $\$ 1^{\circ}$, inc. IV.

${ }^{99} \mathrm{CDC}$, art. $6^{\circ}$, inc. III.

${ }^{100}$ Lei n. 11.105/2005, art. 40- Os alimentos e ingredientes alimentares destinados ao consumo humano ou animal que contenham ou sejam produzidos a partir de OGM ou derivados deverão conter informação nesse sentido em seus rótulos, conforme regulamento.
}

OGMs sem que conste a informação em rótulos e embalagens, de modo que o cidadão consome sem saber o que ${ }^{101}$, constatando verdadeiro desrespeito e oposição ao direito à informação ${ }^{102}$. Respectivamente tornam-se conhecidos resultados alarmantes de pesquisas realizadas para avaliar os efeitos que agrotóxicos e transgênicos podem provocar na saúde pública $^{103}$, em que cientistas descobriram que ratos expostos mesmo a pequenas quantidades do herbicida Roundup da Monsanto e do milho geneticamente modificado, resistente ao Roundup NK603, também desenvolvido pela Monsanto, geraram tumores mamários e graves lesões no fígado e rim num curto espaço de tempo, de quatro meses em machos e sete meses em fêmeas, comparado com 23 e 14 meses nos machos e fêmeas do grupo de controle que não foi submetido à essas substâncias. A exemplo da complexidade que permeia a vida na sociedade moderna, cientistas do Centro de Energia Nuclear na Agricultura, da Universidade de São Paulo - USP de Piracicaba, e da Universidade Estadual de Campinas - UNICAMP, coordenada por Luiz Antonio Martinelli revelam que algumas das cervejas mais consumidas no país alcançam teor de milho e outras gramíneas tropicais acima de $45 \%{ }^{104}$. Desse modo, revela-se o estado de extrema incerteza e insegurança do uso e consumo de transgênicos e produtos mascarados pelo greenwashing, ao se exaltar o Brasil um dos maiores produtores de alimentos transgênicos no mundo ${ }^{105}$, mas que a ciência ainda não consegue

\footnotetext{
${ }^{101}$ Instituto Brasileiro de Defesa do Consumidor. Brasil já é o segundo maior produtor mundial de transgênicos. Disponível em: <http://www. idec.org.br/em-acao/em-foco/brasil-ja-e-o-segundo-maior-produtormundial-de-transgenicos>. Acesso em: 10 out. 2014; Articulação Nacional de Agroecologia. Transgênicos que não estão no rótulo. Disponível em: $<$ http://www.agroecologia.org.br/index.php/noticias/146-transgenicosque-nao-estao-no-rotulo>.

${ }^{102}$ ABREU, Kátia. Projeto de Decreto Legislativo n. 90, de 2007. Disponível em: <http://www.senado.gov.br/publicacoes/diarios/pdf/ sf/2007/05/15052007/14391.pdf>. Acesso em: 10 out. 2014; HEINZE, Luis Carlos. Projeto de Lei, de 2008. Disponível em: <http://www.camara.gov. $\mathrm{br} /$ proposicoesWeb/prop_mostrarintegra?codteor $=605180>$. Acesso em: 10 out. 2014.

${ }^{103}$ BORTOLETTO Ana Paula; JÚNIOR, Flavio Siqueira. Cerveja: o transgênico que você bebe? Outras palavras: comunicação compartilhada e pós-capitalismo. Disponível em: <http://outraspalavras.net/brasil/cerveja-o-transgenico-que-voce-bebe/>. Acesso em: 10 out. 2014.

${ }^{104}$ LOPES, Reinaldo José. Cerveja nacional tem muito milho afirma pesquisa da USP. Folha de S. Paulo. Disponível em: <http://www1.folha.uol com.br/ciencia/2012/10/1164823-cerveja-nacional-tem-muito-milho-afirma-pesquisa-da-usp.shtml >. Acesso em: 10 out. 2014.

${ }^{105}$ UOL. Brasil tem $2^{2}$ maior área de transgênicos, e a que mais cresce no mundo. Disponível em: Disponível em: <http://economia.uol.com.br/ agronegocio/noticias/redacao/2014/02/14/brasil-tem-2-maior-cultivo-e-
} 
responder efetivamente os possíveis efeitos do uso e consumo dos OGMs na saúde e ambiente, principalmente a longo prazo, e diante da manipulação da indústria e interesses capitalistas, destacam apenas vantagens econômicas e menosprezam impactos que podem ser desencadeados.

Assim, a informação dirigida aos consumidores deve ser idônea, clara e adequada, de modo a permitir escolhas informadas, direito também reconhecido na Resolução 39, da $248^{\text {a }}$ Assembleia das Nações Unidas, de 16.04.1985. Essa Resolução trata da proteção do consumidor e entre suas orientações está proteção aos consumidores de perigos à sua saúde e segurança, acesso à informação capacitando à escolhas adequadas, educação para o consumo, padrão de qualidade e segurança de produtos, serviços e alimentos saudáveis ${ }^{106}$

A existência de OGM na composição de algum alimento precisa ser objetiva e ostensivamente informada para garantir o conhecimento e discernimento do consumidor, e para isso a rotulagem é indispensável. A rotulagem, definida no ponto 2.2 da Portaria da Anvisa n. 2.658, de 22.11.2003 é "toda inscrição, legenda, imagem ou toda matéria descritiva ou gráfica que seja escrita, impressa, estampada, gravada, gravada em relevo ou litografada ou colada sobre a embalagem". Logo, o rótulo deve informar característica, composição e conteúdo, destinado a verificação do produto, e no caso específico, da introdução e comercialização de OGMs e transgênicos no mercado consumidor ${ }^{107}$.

O Decreto n. 4.680, de 24.4.2003 regulamenta o direito à informação assegurado pelo direito do consumidor quanto aos alimentos e ingredientes alimentares destinados ao consumo humano ou animal que contenham ou sejam produzidos a partir de

\footnotetext{
producao-de-transgenicos-que-mais-cresce.htm>. Acesso em: 10 out. 2014. ${ }^{106}$ Resolução da Organização das Nações Unidas - ONU nº 39/248, de 1985. Especificamente na seção F, a Resolução traça orientações para governos e empresas encorajar e desenvolver programas de educação e informação ao consumidor com o objetivo de capacitar as pessoas a agirem como consumidores exigentes, conscientes de seus direitos e responsabilidades. Disponível em: <http://www.egov.ufsc.br/portal/conteudo/resolu\%C3\%A7\%C3\%A3oda-organiza $\%$ C3\%A7\%C3\%A3o-das-na $\%$ C3\%A7\%C3\%B5es-unidas-onun\%C2\%BA-39248-de-16-de-abril-de-1985-em-ingl\%C3\%AAs>. Acesso em: 18 set. 2014

${ }^{107}$ KUNISAWA, Viviane Yumy M. O direito de informação do consumidor e a rotulagem dos alimentos geneticamente modificados. Revista do Direito do Consumidor. n. 53, jan.- mar., São Paulo: Editora Revista dos Tribunais, 2005. p. $135-150$, p. $136-140$.
}

OGMs, e estabelece a rotulagem para a comercialização de produto com presença acima do limite de $1 \%$ de OGM. Assim, estipulou-se o rótulo dos produtos, tanto nos vendidos embalados como aqueles à granel ou in natura, com expressões que permitam o consumidor diferenciá-lo dos demais sem alterações genética, como, dependendo do caso, "(nome do produto) transgênico", "contém (nome do ingrediente ou ingredientes) transgênico(s)" ou "produto produzido a partir de (nome do produto) transgênico". Os alimentos e ingredientes produzidos a partir de animais alimentados com ração contendo ingredientes transgênicos também deverão trazer no rótulo as expressões "(nome do animal) alimentado com ração contendo ingrediente transgênico" ou "(nome do ingrediente) produzidos a partir de animais alimentados com ração contendo ingrediente transgênico" 108 .

O $\S 1^{\circ}$ do art. $2^{\circ}$ do Decreto n. 4.680, de 24.4.2003 estabeleceu que conjunto às expressões também deve constar no rótulo o símbolo transgênico, que foi definido pelo Ministério da Justiça na Portaria n. 2.658/2003, representado por um triângulo equilátero com a letra " $\mathrm{T}$ " no centro, com bordas e letra pretas e fundo amarelo, podendo também ser impresso em preto e branco.

Em todos casos, é importante consignar que o desenvolvimento, cultivo e consumo de Alimentos Transgênicos e OGMs confere ao fornecedor o dever de informação e rotulagem, a ser fiscalizado por órgãos federais, estaduais, municipais e do Distrito Federal e o não cumprimento desse dever pode configurar publicidade enganosa e abusiva nos termos do art. $37^{109}$ do CDC, sujeitando à penalidades

\footnotetext{
${ }^{108}$ Decreto $4.680 / 2003$, art. $2^{\circ}$ caput e $\$ 1^{\circ}$, e art. $3^{\circ}$.

${ }^{109} \mathrm{CDC}$, art. 37 - É proibida toda publicidade enganosa ou abusiva.

$\$ 1^{\circ}$ É enganosa qualquer modalidade de informação ou comunicação de caráter publicitário, inteira ou parcialmente falsa, ou, por qualquer outro modo, mesmo por omissão, capaz de induzir em erro o consumidor a respeito da natureza, características, qualidade, quantidade, propriedades, origem, preço e quaisquer outros dados sobre produtos e serviços.

$\$ 2^{\circ}$ É abusiva, dentre outras a publicidade discriminatória de qualquer natureza, a que incite à violência, explore o medo ou a superstição, se aproveite da deficiência de julgamento e experiência da criança, desrespeita valores ambientais, ou que seja capaz de induzir o consumidor a se comportar de forma prejudicial ou perigosa à sua saúde ou segurança. $\$ 3^{\circ}$ Para os efeitos deste código, a publicidade é enganosa por omissão quando deixar de informar sobre dado essencial do produto ou serviço.
} 
administrativas ${ }^{110}$, civis $^{111}$ e penais.

É sobretudo, em função do conhecimento de que os reflexos das nossas ações e escolhas produzem efeitos que repercutem no todo, que produtos agrotóxicos, OGMs e transgênicos devem conter informações no seu respectivo rótulo, descrevendo pesquisas e resultados oficiais, de modo a expressar os potenciais benefícios e perigos com a produção e consumo desses produtos, porque guardam correspondência à vida e ao ambiente e todos demais direitos fundamentais resguardados na CRFB/88.

\section{Conclusão}

O objetivo da abordagem articulada do direito à informação, direito à informação ambiental e direito à informação do consumidor, é demonstrar que a informação, como diz Morin, é apenas o ponto de partida, e por isso essencial seu fornecimento, adequação, veracidade e transparência, como instrumento que não se limita a orientar as condutas humanas na sociedade, mas permite a conscientização da responsabilidade compartilhada da sociedade, por meio do comportamento social, para a salvaguarda do ambiente sadio e equilibrado.

Através da revisão de literatura, levantamento bibliográfico e legislativo constatamos que o direito à informação guarda correspondência direta ao direito fundamental à saúde, à alimentação, ao ambiente ecologicamente equilibrado, resguardados pela CRFB/88 e incumbe, assim, o Poder Público controlar a produção, a comercialização e o emprego

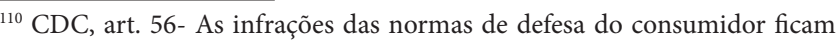
sujeitas, conforme o caso, às seguintes sanções administrativas, sem prejuízo das de natureza civil, penal e das definidas em normas específicas: I - multa; II - apreensão do produto; III - inutilização do produto; IV - cassação do registro do produto junto ao órgão competente; $\mathrm{V}$ - proibição de fabricação do produto; VI - suspensão de fornecimento de produtos ou serviço; VII - suspensão temporária de atividade; VIII - revogação de concessão ou permissão de uso; IX - cassação de licença do estabelecimento ou de atividade; $\mathrm{X}$ - interdição, total ou parcial, de estabelecimento, de obra ou de atividade; XI - intervenção administrativa; XII - imposição de contrapropaganda. $\mathrm{Pa}-$ rágrafo único. As sanções previstas neste artigo serão aplicadas pela autoridade administrativa, no âmbito de sua atribuição, podendo ser aplicadas cumulativamente, inclusive por medida cautelar, antecedente ou incidente de procedimento administrativo.

111 Pratos Limpos. Justiça obriga produtos Pullman, Ana Maria e Bisnaguito a identificar conteúdo transgênico. Disponível em: $<\mathrm{http} / /$ pratoslimpos.org.br/?tag=rotulagem $>$; Ecodebate: cidadania e meio ambiente. Ministério da Justiça processa indústrias que não informam presença de transgênicos em alimentos. Disponível em: <http://www. ecodebate.com.br/2011/03/17/ministerio-da-justica-processa-industriasque-nao-informam-presenca-de-transgenicos-em-alimentos/>. Acesso em: 10 out. 2014.
}

de técnicas, métodos e substâncias que comportem risco à vida e ao ambiente.

As transformações pelas quais a sociedade passa, com o progresso da Sociedade da Informação, as políticas de incentivo ao consumo e os avanços científicos não devem servir para alienar o sujeito, mas ao contrário, para redefinir o processo civilizatório, admitindo o paradigma axiológico do Estado Socioambiental de Direito.

Diante das incertezas quanto o que as evoluções científicas implicam, e como se distanciam entre o ideal e o real, a Sociedade da Informação precisa enfrentar as questões do consumo ostensivo, instruindo sobre os potenciais benefícios e prejuízos do consumo de alimentos transgênicos e as questões que se desenvolvem com o avanço tecnológico, democratizando a informação sobre as interferências ambientais, para que os direitos fundamentais da população possam ser preservados.

Somente com o respeito à obrigação da rotulagem de transgênicos e a consciência dos possíveis risco à saúde e ao ambiente é possível assegurar o controle social pelo exercício da livre escolha e consumo consciente.

Assim, para incentivar esse direito de participação cidadã é preciso primeiro garantir o direito à informação idônea, um direito passivo eativo para o conhecimento e conscientização. A sociedadecivil pode e deve participar das decisões que refletem sobre o todo e o direito à informação contribui à interação mais respeitosa do homem com o ambiente e implementação do Estado Socioambiental de Direito.

\section{Referência das fontes citadas}

ABREU, Kátia. Projeto de Decreto Legislativo n. 90, de 2007. Disponível em: <http://www.senado.gov.br/ publicacoes/diarios/pdf/sf/2007/05/15052007/14391.pdf>. Acesso em: 10 out. 2014;

ALBUQUERQUE, José Lima (Org.). Gestão ambiental e responsabilidade social: conceitos, ferramentas e aplicações. São Paulo: Atlas, 2009.

ACSELRAD, Henri. A irresponsabilidade ambiental organizada. Disponível em: $<$ http://www.justicaambiental. org.br/v2/admin/anexos/acervo/17_030408_artigo_ irresposabilidade_ambiental_organizada_henri.pdf $>$. Acesso em: 13 jan. 2015. 
AUGUSTINI, Camila; VARON, Joana; CARIBÉ, Pedro. Wi-fi? Projeto Freenet? Disponível em: $<$ http://www. diplomatique.org.br/multimidia.php?id $=38>$. Acesso em: 27 set. 2014

BARROS, Lucivaldo Vasconcelos. Direito à informação socioambiental e desenvolvimento sustentável. Revista de Direito Ambiental. Ano 12, n. 45, jan.-mar.2007, p. 167183.

BAUMAN, Zygmunt. Vida para consumo: a transformação das pessoas em mercadoria. Tradução Carlos Alberto Medeiros. Rio de Janeiro: Zahar, 2008.

BÁRCENA, Alicia et al. Los transgénicos en América Latina y el Caribe: un debate abierto. Santiago de Chile: Naciones Unidas, 2004.

BORTOLETTO Ana Paula; JÚNIOR, Flavio Siqueira. Cerveja: o transgênico que você bebe? Outras palavras: comunicação compartilhada e pós-capitalismo. Disponível em: <http://outraspalavras.net/brasil/cerveja-o-transgenicoque-voce-bebe/>. Acesso em: 10 out. 2014.

BOFF, Leonardo. A águia e a galinha: uma metáfora da condição humana. 32 ed. Petrópolis, RJ: Editora Vozes, 1999.

BRASIL. Lei n. 6.938/1981. Dispõe sobre a Política Nacional do Meio Ambiente, seus fins e mecanismos de formulação e aplicação, e dá outras providências. Disponível em: $<\mathrm{http}: / /$ www.planalto.gov.br/ccivil_03/Leis/L6938.htm>. Acesso em: 12 mar. 2014.

Lei n. 7.347, de 24 de julho de 1985. Disciplina a ação civil pública de responsabilidade por danos causados ao meio-ambiente, ao consumidor, a bens e direitos de valor artístico, estético, histórico, turístico e paisagístico (VETADO) e dá outras providências. Disponível em: $<$ http:// www.planalto.gov.br/ccivil_03/leis/17347orig.htm>. Acesso em: 12 mar. 2014

Constituição da República Federativa do Brasil. Brasília, DF: Senado Federal, 1988.

Decreto n. 99.274, de 6 de junho de 1990. Regulamenta a Lei n. 6.902, de 27 de abril de 1981, e a Lei n. 6.938, de 31 de agosto de 1981, que dispõem, respectivamente sobre a criação de Estações Ecológicas e Áreas de Proteção Ambiental e sobre a Política Nacional do Meio Ambiente, e dá outras providências. Disponível em: <http://www. planalto.gov.br/ccivil 03/decreto/antigos/d99274.htm>. Acesso em 12 mar. 2014

Lei n.8.078, de 11 de setembro de 1990. Dispõe sobre a proteção do consumidor e dá outras providências. Disponível em: <http://www.planalto.gov.br/ccivil_03/leis/ 18078.htm>. Acesso em: 27 set. 2014.

Lei n. 10.406, de 10 de janeiro de 2002. Institui o Código Civil. Disponível em: <http://www.planalto.gov.br/ ccivil_03/leis/2002/110406.htm>. Acesso em: 12 mar. 2014.
Lei n. 10.650, de 16 de abril de 2003. Dispõe sobre o acesso público aos dados e informações existentes nos órgãos e entidades integrantes do Sisnama. Disponível em: $<$ http://www.planalto.gov.br/ccivil_03/Leis/2003/L10.650. htm>. Acesso em: 12 mar. 2014.

Decreto n. 4.680, de 24 de abril de 2003. Regulamenta o direito à informação, assegurado pela Lei n. 8.078, de 11 de setembro de 1990, quanto aos alimentos e ingredientes alimentares destinados ao consumo humano ou animal que contenham ou sejam produzidos a partir de organismos geneticamente modificados, sem prejuízo do cumprimento das demais normas aplicáveis. Disponível em: $<$ http://www. planalto.gov.br/ccivil 03/decreto/2003/d4680.htm> Acesso em: 12 mar. 2014.

. ANVISA. Agência Nacional de Vigilância Sanitária. Portaria n. 2.658, de 22 nov. 2003. Definir o símbolo de que trata o art. $2^{\circ}, \S 1^{\circ}$, do Decreto n. 4.680 , de 24 de abril de 2003, na forma do anexo à presente portaria. Disponível em: <http://portal.anvisa.gov.br/wps/wcm/connect/1e3d43 804ac0319e9644bfa337abae9d/Portaria_2685_de_22_de dezembro de 2003.pdf?MOD=AJPERES $>$. Acesso em: $1 \overline{1}$ out.2014.

Lei n. 11.105, de 24 de março de 2005. Regulamenta os incisos II, IV e V do $\S 1$ o do art. 225 da Constituição Federal, estabelece normas de segurança e mecanismos de fiscalização de atividades que envolvam organismos geneticamente modificados - OGM e seus derivados, cria o Conselho Nacional de Biossegurança-CNBS, reestrutura a Comissão Técnica Nacional de Biossegurança - CTNBio, dispõe sobre a Política Nacional de Biossegurança - PNB, revoga a Lei n. 8.974, de 5 de janeiro de 1995, e a Medida Provisória no 2.191-9, de 23 de agosto de 2001, e os arts. $5^{\circ}$, $6^{\circ}, 7^{\circ}, 8^{\circ}, 9^{\circ}, 10$ e 16 da Lei n. 10.814 , de 15 de dezembro de 2003, e dá outras providências. Disponível em: $<\mathrm{http}: / / \mathrm{www}$. planalto.gov.br/ccivil_03/_ato2004-2006/2005/lei/111105. $\mathrm{htm}>$. Acesso em: 12 mar. 2014.

Lei n. 11.346, de 15 de setembro de 2006. Cria o Sistema Nacional de Segurança Alimentar e Nutricional - SISAN com vistas em assegurar o direito humano à alimentação adequada e dá outras providências. Disponível em: <http://www.planalto.gov.br/ccivil_03/_ato20042006/2006/lei/111346.htm>. Acesso em: 12 mar. 2014.

BRAVO, Álvaro A. Sánchez. Internet y lasociedadeuropea de lainformación: implicaciones para losciudadanos. Fragmento disponível para visualização em: <http:// books.google.com.br/books?id=vgu7ggfCYN4C\&pg=P $\mathrm{A} 12 \& \operatorname{lpg}=\mathrm{PA} 12 \& \mathrm{dq}=$ alvaro $+\mathrm{a}+\mathrm{s} \% \mathrm{C} 3 \% \mathrm{~A} 1 \mathrm{nchez}+$ bravo + sociedad + de + la + informaci $\%$ C3\%B3n\&source $=$ bl\&ots $=\mathrm{KQ} 0-\mathrm{r} 7 \mathrm{vzSf} \&$ sig $=\mathrm{QWT}$ 7pTURafDf7X38KOcIiFLiC0 $\& \mathrm{hl}=\mathrm{ptBR} \& \mathrm{sa}=\mathrm{X} \& \mathrm{ei}=\mathrm{aJtLVJK} 0 \mathrm{LIrxgwSOz} 4 \mathrm{DQCg} \& \mathrm{v}$ $\mathrm{ed}=0 \mathrm{CDwQ} 6 \mathrm{AEwAw} \# \mathrm{v}=$ onepage $\& \mathrm{q}=$ alvaro $\% 20 \mathrm{a} \% 20$ s\%C3\%A1nchez \%20bravo\%20sociedad \%20de\%201a\%20 informaci\%C3\%B3n\&f=false>. Acesso em 25 out. 2014. 
Centro de Genética Molecular: Centro de Formação Genética e certificação molecular. Disponível em: <http:// www.cgm.icb.ufmg.br/oquesao.php $>$. Acesso em: 7 out. 2014.

Conselho Nacional de Autorregulamentação de Publicidade. Disponível em: <http://www.conar.org.br/>. Acesso em: 6 out. 2014.

Convenção de Aarhus. Agência Portuguesa do Ambiente. Disponível em: <http://www.apambiente.pt/index.php?ref= $16 \&$ subref $=142 \&$ sub2 $\mathrm{ref}=726 \&$ sub3ref $=727>$. Acesso em: 20 set. 2014.

Convenção sobre Acesso à Informação, Participação do Público no Processo de Tomada de Decisão e Acesso à Justiça em Matéria de Ambiente. Disponível em: <http:// www.unece.org/fileadmin/DAM/env/pp/EU\%20texts/ conventioninportogese.pdf $>$. Acesso em: 20 set. 2014.

Declaração do Rio de Janeiro sobre meio ambiente desenvolvimento - ECO-92. VEJA. Disponível em: <http:// veja.abril.com.br/complementos-materias/rio+20-widgets/ pdf/declaracao-do-rio-de-janeiro-sobre-meio-ambientedesenvolvimento.pdf>. Acesso em: 4 out. 2014.

Ecodebate: cidadania e meio ambiente. Ministério da Justiça processa indústrias que não informam presença de transgênicos em alimentos. Disponível em: <http:// www.ecodebate.com.br/2011/03/17/ministerio-da-justicaprocessa-industrias-que-nao-informam-presenca-detransgenicos-em-alimentos/>. Acesso em: 10 out. 2014.

FERREIRA, HelineSivini; FERREIRA, Maria Leonor Paes Cavalcanti. Registro e importação de agrotóxicos: não seria dever do Poder Público controlar as atividades que envolvem substâncias capazes de causar danos à vida, à qualidade de vida e ao meio ambiente? In: FERREIRA, HelineSivini; FERREIRA, Maria Leonor Paes Cavalcanti (Org.). Dano ambiental na sociedade de risco. São Paulo: Saraiva, 2012. p. 185-212.

FERRER, Gabriel Real. La construccióndelderecho ambiental. Revista Aranzadi de Derecho Ambiental. (Pamplona, Espanha), n.1, 2002, p. 73-93.

FIORILlO, Celso Antonio Pacheco. Fundamentos constitucionais do meio@mbientedigit@1 na sociedade da informação. In: Paesani, Liliana. $O$ direito na sociedade da informação III: A evolução do direito digital, v.3, Atlas, 2013. VitalBook file. Minha Biblioteca. Disponível em: <http:// online.minhabiblioteca.com.br/books/9788522482139>. Acesso em 9 set. 2014.

FISCHER, Karla Ferreira de Camargo. A problemática dos alimentos transgênicos e o direito do consumidor à informação. Cadernos da Escola de Direito e Relações Internacionais das Faculdades do Brasil. Curitiba, v. 1, n. 1, mar.-ago. 2002, p. 119- 139.
FREITAS, Juarez. Sustentabilidade: direito ao futuro. Belo Horizonte: Editora Fórum, 2011.

GOERG, Paula. Greenwashing no Brasil: um estudo sobre os apelos ambientais nos rótulos. Disponível em: <http:// marketanalysis.com.br/wp-content/uploads/2014/09/ Greenwashing_2014_MarketAnalysis.pdf $>$. Acesso em: 6 out. 2014

GOMES, Carla Amado. A caminho de uma ecocidadania: notas sobre o direito à informação ambiental. Revista de Direito Ambiental. Ano 12, n. 45, jan.-mar.2007, p. 259272.

GOMES, Eduardo de Castro. A escrita na história da humanidade. Disponível em: <http://dialogica.ufam.edu.br/ PDF/no3/Eduardo_Aspectos_da_escrita_na_Historia_da_ humanidade.pdf $>$. A cesso em: 24 set. $201 \overline{4}$.

HEINZE, Luis Carlos. Projeto de Lei, de 2008. Disponível em: <http://www.camara.gov.br/proposicoesWeb/prop mostrarintegra?codteor $=605180>$. Acesso em: 10 out. 2014 .

Instituto Akatu. Disponível em: <http://www.akatu.org. br/>. Acesso em: 6 out. 2014.

Instituto Brasileiro de Defesa do Consumidor. Brasil já é o segundo maior produtor mundial de transgênicos. Disponível em: <http://www.idec.org.br/em-acao/emfoco/brasil-ja-e-o-segundo-maior-produtor-mundial-detransgenicos>. Acesso em: 10 out. 2014.

KUNISAWA, Viviane Yumy M. O direito de informação do consumidor e a rotulagem dos alimentos geneticamente modificados. Revista do Direito do Consumidor. n. 53, jan.- mar., São Paulo: Editora Revista dos Tribunais, 2005. p. $135-150$.

LISBOA, Roberto Senise. Direito na sociedade da informação. Revista dos Tribunais. Ano. 95, vol. 847, mai.2006, p. 78-95.

LOPES, Reinaldo José. Cerveja nacional tem muito milho afirma pesquisa da USP. Folha de S. Paulo. Disponível em: $<$ http://www1.folha.uol.com.br/ciencia/2012/10/1164823cerveja-nacional-tem-muito-milho-afirma-pesquisa-da-usp. shtml>. Acesso em: 10 out. 2014.

MACHADO, Paulo Affonso Leme. Direito ambiental brasileiro. 12. ed. São Paulo: Malheiros, 2004.

Direito à informação e meio ambiente. São Paulo: Malheiros, 2006.

MORIN, EDGAR. Introdução ao pensamento complexo. Tradução de Eliane Lisboa. 3 ed. Porto Alegre: Sulina, 2007.

Pratos Limpos. Justiça obriga produtos Pullman, Ana Maria e Bisnaguito a identificar conteúdo transgênico. Disponível em: <http://pratoslimpos.org. $\mathrm{br} /$ ?tag=rotulagem $>$; 
REHBINDER, Eckard. Democracy, acessto justice andenvironmentatthe internacional level. Disponível em: $\quad<$ http://www.cidce.org/pdf/livre\%20rio/rapports $\% 20$ g\%C3\%A9n\%C3\%A9raux/rehbinder.pdf $>$. Acesso em: 28 ago. 2014.

Resolução da Organização das Nações Unidas - ONU $\mathbf{n}^{\mathbf{0}}$ 39/248, de 1985. Disponível em: <http://www.egov. ufsc.br/portal/conteudo/resolu $\% \mathrm{C} 3 \% \mathrm{~A} 7 \% \mathrm{C} 3 \% \mathrm{~A} 3 \mathrm{o}-$ d a - o r g a n i z a \% C $3 \%$ A $7 \%$ C $3 \%$ A 3 o-d a s na $\% \mathrm{C} 3 \% \mathrm{~A} 7 \% \mathrm{C} 3 \% \mathrm{~B} 5$ es-unidas-onu-n $\% \mathrm{C} 2 \% \mathrm{BA}-39248$ de-16-de-abril-de-1985-em-ingl $\%$ C3\%AAs>. Acesso em: 18 set. 2014.

RODRIGUES, Melissa Cachoni; ARANTES, Olivia Marcia Nagy. Direito ambiental e biotecnologia: uma abordagem sobre os transgênicos sociais. $1^{\mathrm{a}}$ ed. (ano 2004) $2^{\mathrm{a}}$ tir. Curitiba: Juruá, 2005.

SHIVA, Vandana. Monoculturas da mente: perspectivas da biodiversidade e da biotecnologia. Trad. Dinah de Abreu Azevedo. São Paulo: Editora Gaia, 2003.

SIQUEIRA JR., Paulo Hamilton. Direito informacional: direito da sociedade da informação. Revista dos Tribunais, ano 96, vol. 859, mai. 2007, p. 743- 759.

SILVA, Brisa Arnoud da. Do Estado Liberal para Socioambiental de Direito: o caminho para o desenvolvimento sustentável. In: SOUZA, Maria Claudia da Silva Antunes de; ARMADA, Charles Alexandre Souza (Org.). Teoria jurídica e Transnacionalidade. vol. II, 2014, p. 130-152. Disponível em: $<$ http://www.univali.br/ppcj/ebook $>$. Acesso em: 21 jul.2014.

SILVA, Telma Domingues da. Educação ambiental: a educação para o consumo na sociedade da informação. Linguagem em (Dis)curso [online], Tubarão, SC, v. 11, n. 3, p. 563-584, set./dez. 2011, p. 570. Disponível em: $<$ http:// www.scielo.br/scielo.php?script $=$ sci arttext\&pid $=\mathrm{S} 1518$ $76322011000300006 \& \operatorname{lng}=\mathrm{en} \& \mathrm{nrm}=\mathrm{iso}>$. Acesso em: 11 set. 2014.

SOARES, Ricardo Maurício Freire. Direito, justiça e princípios constitucionais. Salvador: Jus Podivm, 2008.

Transgênicos que não estão no rótulo. Disponível em: $<$ http://www.agroecologia.org.br/index.php/noticias/146transgenicos-que-nao-estao-no-rotulo $>$. Acesso em: 10 out. 2014.

UOL. Brasil tem $2^{\mathrm{a}}$ maior área de transgênicos, e a que mais cresce no mundo. Disponível em: <http://economia. uol.com.br/agronegocio/noticias/redacao/2014/02/14/brasiltem-2-maior-cultivo-e-producao-de-transgenicos-que-maiscresce.htm>. Acesso em: 10 out. 2014.

VAZ, Paulo Afonso Brum. O direito ambiental e os agrotóxicos: responsabilidade civil, penal e administrativa. Porto Alegre: Livraria do Advogado, 2006.
VITAL Nicholas. Luz para poucos: Apesar de toda a propaganda em torno do programa Luz para Todos, há ainda 2,5 milhões de residências no país sem acesso à energia elétrica. Revista Exame. 29 dez. 2010. Disponível em: $<$ http://planetasustentavel.abril.com.br/noticia/energia/ muitas-casas-falta-eletricidade-programa-luz-todosexame-615327.shtml? func $=1 \& p a g=0 \&$ fnt $=14 p x>$. Acesso em: 29 set. 2014. 